\title{
Analysis of first recurrence and survival in patients with stage I non-small cell lung cancer treated with surgical resection or stereotactic radiation therapy
}

Traves D. Crabtree, MD, ${ }^{a}$ Varun Puri, MD, ${ }^{a}$ Clifford Robinson, MD,${ }^{c}$ Jeffrey Bradley, MD, ${ }^{c}$ Stephen Broderick, MD, ${ }^{a}$ G. Alexander Patterson, MD, ${ }^{a}$ Jingxia Liu, PhD, ${ }^{\text {b }}$ Joanne F. Musick, RN, ${ }^{a}$ Jennifer M. Bell, BSN, ${ }^{a}$ Michael Yang, BS, ${ }^{a}$ and Bryan F. Meyers, MD, MPH ${ }^{a}$

Objectives: Comparative studies of survival between stereotactic body radiation therapy (SBRT) and surgery have been limited by lack of comparisons of recurrence patterns between matched cohorts in non-small cell lung cancer (NSCLC).

Methods: All patients undergoing treatment with surgery or SBRT for clinical stage I NSCLC between June 2004 and December 2010 were reviewed. Age, tumor characteristics, comorbidity score, pulmonary function, overall survival (OS), disease-free survival (DFS), and recurrence data were collected and propensity matching performed.

Results: The mean age for surgery $(\mathrm{n}=458)$ was $65.8 \pm 10.5$ versus $74.4 \pm 9.4$ for SBRT $(\mathrm{n}=151)(P<.0001)$. For the entire surgical cohort, 3-year OS was $78 \%$ and DFS was $72 \%$. For the entire SBRT cohort, 3-year OS was $47 \%$ and DFS was $42 \%$. The overall local recurrence rate for surgery was $2.6 \%$. The overall local recurrence rate for SBRT was $10.7 \%$. A propensity-matched comparison based on age, tumor size, Adult Comorbidity Evaluation comorbidity score, forced expiratory volume in the first second of expiration, and tumor location resulted in 56 matched pairs. The 3 -year OS was $52 \%$ versus $68 \%$ for SBRT and surgery $(P=.05)$; DFS was $47 \%$ versus $65 \%(P=.01)$. At 3 years, local recurrence-free survival was $90 \%$ versus $92 \%$ for SBRT and surgery $(P=.07)$.

Conclusions: Although surgical resection seems to result in better OS and DFS versus SBRT, matching these disparate cohorts of patients remains challenging. Participation in clinical trials is essential to define the indications and relative efficacy of surgery and radiation therapy in a high-risk population with stage I NSCLC.

(J Thorac Cardiovasc Surg 2014;147:1183-92)

\section{Supplemental material is available online.}

From the Division of Cardiothoracic Surgery, Department of Surgery, ${ }^{\mathrm{a}}$ Division of Biostatistics, ${ }^{\mathrm{b}}$ Department of Radiation Oncology, ${ }^{\mathrm{c}}$ Washington University School of Medicine, St Louis, Mo.

Research reported in this publication was supported by the Washington University Institute of Clinical and Translational Sciences grant UL1 TR000448 from the National Center for Advancing Translational Sciences of the National Institutes of Health.

Disclosures: Traves D. Crabtree has received payment for consultancy and lecturing for Ethnicon Endo-Surgery, Inc. Bryan Meyers has been a consultant and lectured for Ethnicon Endo-Surgery, Inc, and Varian Medical Systems, Inc, and has been a consultant for Covidien. All other authors have nothing to disclose with regard to commercial support.

The content is solely the responsibility of the authors and does not necessarily represent the official view of the National Institutes of Health.

Read at the 93rd Annual Meeting of The American Association for Thoracic Surgery, Minneapolis, Minnesota, May 4-8, 2013.

Received for publication May 6, 2013; revisions received Nov 21, 2013; accepted for publication Nov 29, 2013; available ahead of print Feb 7, 2014.

Address for reprints: Traves D. Crabtree, MD, Cardiothoracic Surgery, 3108 Queeny Tower, Barnes-Jewish Hospital, One Barnes-Jewish Hospital Plaza, St. Louis, MO 63110 (E-mail: crabtreet@wudosis.wustl.edu).

$0022-5223 / \$ 36.00$

Copyright $\odot 2014$ by The American Association for Thoracic Surgery

http://dx.doi.org/10.1016/j.jtcvs.2013.11.057
Stereotactic body radiation therapy (SBRT) has become the primary treatment of choice for inoperable patients with peripheral stage I lung cancer. Although the role of radiofrequency ablation has yet to be defined for stage I lung cancer, single-center studies and a prospective trial of SBRT have consistently demonstrated good cancer-specific survival in patients deemed inoperable. ${ }^{1-4}$ For SBRT, 3-year survival for stage I lung cancer has been reported to be $56 \%$ to $85 \%$ with primary tumor local recurrence rates less than $10 \%$ at 3 years. ${ }^{2-7}$ These data have highlighted the benefit of this therapy in a cohort of patients who previously went untreated or were inadequately treated with conventional external beam radiation therapy.

Currently, surgical anatomic resection with mediastinal lymphadenectomy remains the standard of care for operable patients with stage I lung cancer. ${ }^{8,9}$ In the contemporary era of video-assisted techniques for anatomic resection, 5-year overall survival (OS) has been reported to be $75 \%$ to $80 \%$ with a perioperative mortality rate of $1 \% .{ }^{10-12}$ In small subsets of potentially operable patients from single-center studies, SBRT has been associated with good primary tumor control and OS. Although such findings are encouraging, these data are not sufficient to supplant surgical resection 


\section{Abbreviations and Acronyms \\ ACE-27 = Adult Comorbidity Evaluation-27 \\ ACOSOG $=$ American College of Surgeons \\ Oncology Group \\ BED = biologically effective dose \\ CT = computed tomography \\ DFS $=$ disease-free survival \\ FDG = 2-deoxy- $2\left[{ }^{18}\right.$ F $]$ fluoro-D-glucose \\ $\mathrm{FEV}_{1}=$ forced expiratory volume in the first second of expiration \\ HIV = human immunodeficiency virus \\ NSCLC $=$ non - small cell lung cancer \\ OS $\quad=$ overall survival \\ PET = positron emission tomography \\ RTOG = Radiation Therapy Oncology Group \\ SBRT = stereotactic body radiation therapy}

as the standard of care in the operable patient and clinical trials are needed to determine whether outcomes after SBRT are comparable with anatomic surgical resection. ${ }^{2,3,13}$

The ambiguous scenario, however, involves the so-called high-risk surgical patient with early stage lung cancer. The American College of Surgeons Oncology Group (ACOSOG) Z4032 trial has recently examined the role of sublobar resection with and without brachytherapy in this subgroup of patients. ${ }^{14}$ The ACOSOG Z4099/Radiation Therapy Oncology Group (RTOG) 1021 trial was an important prospective randomized trial designed to compare outcomes in high-risk patients with stage I lung cancer treated with sublobar resection versus SBRT. ${ }^{15}$ Unfortunately, because of poor accrual, this trial was recently closed. Our institution has published previous comparative studies demonstrating comparable cancer-specific survival after surgery in propensity-matched groups of patients treated with either SBRT or surgery. ${ }^{16-18}$ Limitations of previously published series include small sample size, inadequate follow-up, inconsistent definitions of recurrence between the groups, and inadequate matching of the cohorts.

This study was designed to overcome some of the shortcomings of previously published comparisons. This is a retrospective propensity-matched comparative study using a large cohort of patients undergoing SBRT or surgical resection for stage I lung cancer. This study was designed to compare OS, disease-free survival (DFS), local recurrence, regional recurrence, and distant recurrence using common definitions of recurrence and survival from recent and ongoing clinical trials.

\section{METHODS}

This is a retrospective study of all patients undergoing treatment at our center with surgery or SBRT for clinical stage I non-small cell lung cancer (NSCLC) between June 2004 and December 2010. The patients were treated at the Siteman Cancer Center, a National Cancer Institutedesignated comprehensive cancer center at the Washington University School of Medicine and Barnes-Jewish Hospital in Saint Louis, Missouri. All patients underwent clinical staging with computed tomography (CT) and fluorodeoxyglucose (FDG)-positron emission tomography (PET) imaging. Patients were usually seen initially by a surgeon, and if considered high-risk for lobectomy were referred for SBRT. In the surgical patients, the type of surgical resection performed (ie, lobar vs sublobar), the type of incision, performance of mediastinoscopy, and extent of lymph node dissection was at the discretion of the treating thoracic surgeon. NSCLC was ultimately confirmed histologically in all surgical patients. Patients undergoing SBRT did not undergo routine surgical staging with either mediastinoscopy or endobronchial ultrasonography.

All pretreatment CT scans and FDG-PET scans were reviewed to include only those patients with clinical stage I lung cancer. Comorbidity scores were recorded prospectively using the Adult Comorbidity Evaluation (ACE-27) scoring system (Appendix E1). The Siteman Cancer Center Oncology Data Services in the Clinical Outcomes Research Office at Washington University prospectively assigns comorbidity scores.

Clinic and hospital charts, follow-up CT and FDG-PET scans, as well as follow-up biopsies were reviewed to determine local tumor recurrence, regional and distant recurrence, DFS, and OS. Patients were followed with serial chest radiographs and/or CT scans every 3 to 6 months for the first 2 years and every 6 to 12 months up to 5 years, then yearly afterward. FDG-PET imaging was performed if there was suspicion for recurrence. Local, regional, and distant recurrence definitions were as defined by the current ACOSOG Z4099/RTOG 1021 trial for comparison of SBRT and sublobar resection in high-risk patients. ${ }^{19}$ Briefly, local recurrence included the primary tumor site, marginal, ipsilateral lobar, or port site/wound recurrence. An important distinction in this trial is the definition of local recurrence, which includes both primary tumor failure and (for sublobar resection or SBRT) failure in the involved lobe. In some instances, the diagnosis of the first recurrence occurred simultaneously at different locations accounting for the multiple recurrences noted in some patients. Exclusion criteria included patients with small cell lung cancer or extrathoracic cancers that metastasized to the lung, patients undergoing resection for benign disease, patients without preoperative staging chest $\mathrm{CT}$ and FDG-PET scans, patients with tumors stages or T3 or higher and patients with clinical N1 or N2 disease noted on preoperative imaging. For the SBRT patients, every effort was made to obtain a tissue diagnosis before treatment. A small fraction (14\%) of patients underwent treatment without a tissue diagnosis. These patients were reviewed at our multidisciplinary conference and in all such patients, a radiologist reviewed the images and either attempted a biopsy or deemed a biopsy to be too high risk. These patients were included to demonstrate the practical management of clinical stage I lung cancer in high-risk or inoperable patients and to provide a reference for the proportion of patients treated without a tissue diagnosis relative to other published cohorts.

Details of SBRT planning and delivery at our institution have been described previously. ${ }^{1}$ The Varian Trilogy System was used for all SBRT patients. Target coverage, conformality, and normal tissue constraints were followed according to the protocol for the RTOG 0236 clinical trial. $^{7}$ Prescriptions were typically specified at the $60 \%$ to $90 \%$ (median, $84 \%$ ) isodose line so that at least $95 \%$ of the prescribed dose covered the planning target volume. Most SBRT patients received a biologically effective dose (BED) of at least $100 \mathrm{~Gy}_{10}$ (median dose, $54 \mathrm{~Gy}$ in 3 fractions). BED was calculated using $\mathrm{BED}_{\alpha / \beta}=\mathrm{nd}(1+\mathrm{d} / \alpha / \beta)$, where $n$ is the number of fractions, $d$ is the dose per fraction, and $\alpha / \beta=10$ for tumor in line with previous reports. ${ }^{5,20}$

$\mathrm{BED}_{10}$ for the SBRT regimens used in this study was $85.5 \mathrm{~Gy}_{10}$ (45 Gy in 5 fractions, $\mathrm{n}=6$ ), $86.4 \mathrm{~Gy}_{10}$ ( $48 \mathrm{~Gy}$ in 6 fractions, $\left.\mathrm{n}=1\right), 100 \mathrm{~Gy}_{10}(50$ Gy in 5 fractions, $\mathrm{n}=21$ ), $105.6 \mathrm{~Gy}_{10}(48 \mathrm{~Gy}$ in 4 fractions, $\mathrm{n}=1), 112.5$ $\mathrm{Gy}_{10}$ (45 Gy in 3 fractions, $\mathrm{n}=6$ ), $115.5 \mathrm{~Gy}_{10}(55 \mathrm{~Gy}$ in 5 fractions, $\mathrm{n}=3$ ), $132 \mathrm{~Gy}_{10}\left(60 \mathrm{~Gy}\right.$ in 5 fractions, $\mathrm{n}=4$ ), and $151.2 \mathrm{~Gy}_{10}$ ( $54 \mathrm{~Gy}$ in 3 fractions, $\mathrm{n}=110)$. 
SAS version 9.3 (SAS Institute, Inc, Cary, NC) was used to perform all statistical analyses. Descriptive statistics included the mean \pm standard deviation of continuous variables and counts and proportions of categorical data by group. Continuous and categorical variables were compared by a Kruskal-Wallis test and the chi-squared test, respectively. OS is defined from the date of treatment to the date of death or the last follow-up. DFS was defined as being alive without disease. The patients with disease or those who died are counted as disease. DFS was defined as the time from date of treatment to date of cancer recurrence, death, or last follow-up. Local, regional, or distant recurrence is defined as having local, regional, or distant failure, censored at any other recurrence or at last follow-up. Freedom from local, regional, or distant recurrence is defined as the time from date of treatment to date of recurrence or last follow-up. KaplanMeier curves provided unadjusted survival estimates for patients across strata. Differences between strata were determined by log-rank tests. Based on previously published comparisons, an initial propensity-matched analysis was performed to compare patients in the SBRT and surgery groups based on age, tumor stage, and ACE comorbidity score. To provide additional variables, a subsequent propensity score was estimated using age, forced expiratory volume in the first second of expiration $\left(\mathrm{FEV}_{1}\right.$, $\%$ ), tumor size, tumor location, and ACE comorbidity score. The matched pair was found using a caliper technique with a standard deviation defined as 0.075 of the estimated propensity score for both groups. All statistical tests were 2-sided using an $\alpha=0.05$ level of significance.

The study and a waiver of informed consent were approved by the Washington University School of Medicine Human Research Protection Office.

\section{RESULTS}

Four hundred fifty-eight patients underwent primary surgical resection for clinical stage I NSCLC and 151were treated with SBRT (Figure 1). Table 1 outlines the demographics and preoperative comorbidity comparisons between the unmatched cohorts of surgery and SBRT patients. Surgery patients were younger and had lower comorbidity scores. Median follow-up for the surgery cohort was 2.83 years and the median follow-up for the SBRT cohort was 1.95 years. There were $165(36 \%)$ clinical T2 lesions in the surgery group versus $41(27 \%)$ in the SBRT group $(P=.0456)$. Pathologic N1 and N2 disease were identified in $11.8 \%(\mathrm{n}=54)$ and $3.0 \%$ $(\mathrm{n}=14)$ of surgery patients. In addition, $3.1 \%(\mathrm{n}=14)$ of surgical patients were found to be pathologic T3 and $2.2 \%(\mathrm{n}=10)$ were pathologic T4. Of 293 clinical T1 lesions, $18.4 \%$ (54) were found to be pathologic T2. No patients in the SBRT cohort received adjuvant therapy but $17.5 \%$ (80) were confirmed to have received adjuvant therapy in the surgical cohort. Among surgical resections, $75.6 \%(\mathrm{n}=347)$ underwent lobectomy, 5.9\% $(\mathrm{n}=27)$ underwent pneumonectomy/bilobectomy, and $18.3 \%$ $(\mathrm{n}=84)$ underwent sublobar resection. Thirty-day mortality was $1.09 \%(5 / 458)$ for the surgery group and $0.66 \%$ (1/ 151) for the SBRT group (not significant). The cause of death in the patient who died within 30 days of SBRT treatment was unknown and was defined as a sudden death.

Three-year OS for surgery was $78 \%$ and DFS was $72 \%$ (Figure E1 and Appendix E2). Three-year OS for SBRT was $47 \%$ and DFS was $42 \%$. Table 2 outlines the total proportion of local, regional, and distant recurrences for both cohorts. The overall local recurrence rate for surgery was $2.6 \%$. The local recurrence rate for SBRT was $10.7 \%$.

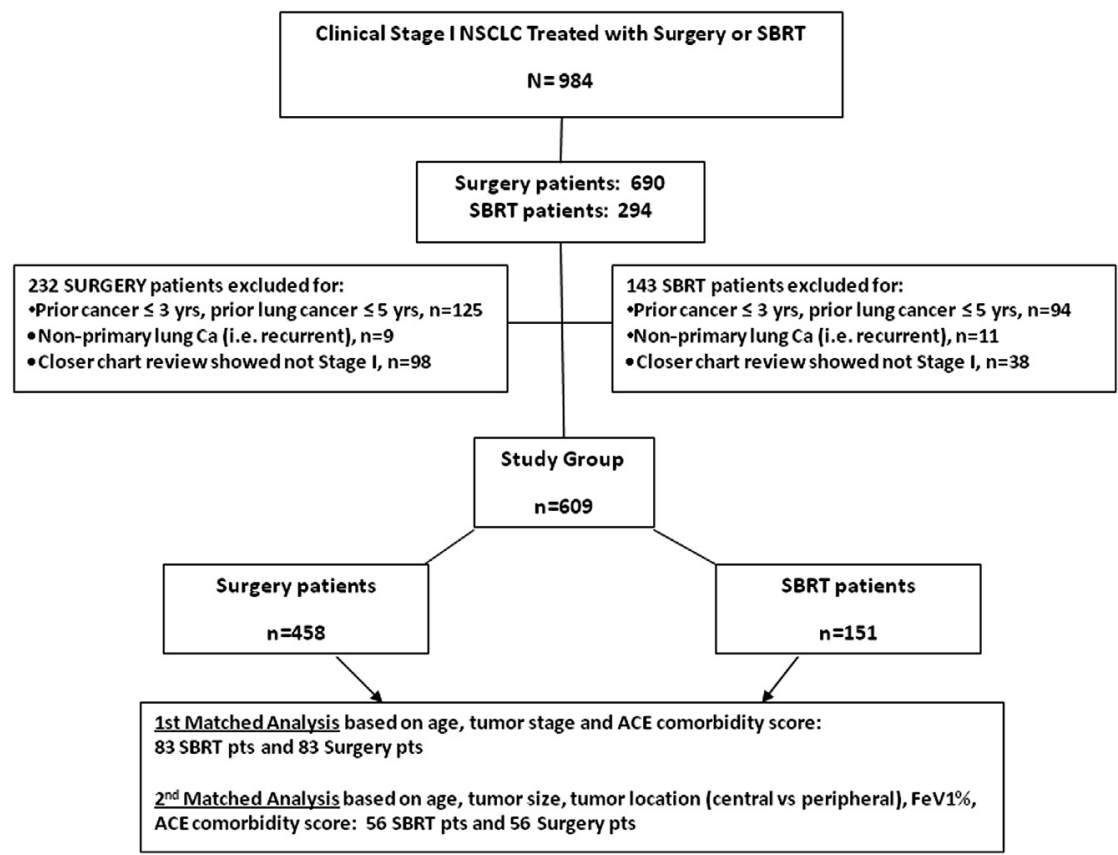

FIGURE 1. CONSORT diagram outlining selection of patients treated with either SBRT or surgery for stage I non-small cell lung cancer. $N S C L C$, Non-small cell lung cancer; SBRT, stereotactic body radiation therapy; $C a$, cancer; $A C E$, Adult Comorbidity Evaluation; $F E V_{l}$, forced expiratory volume in the first second of expiration. 

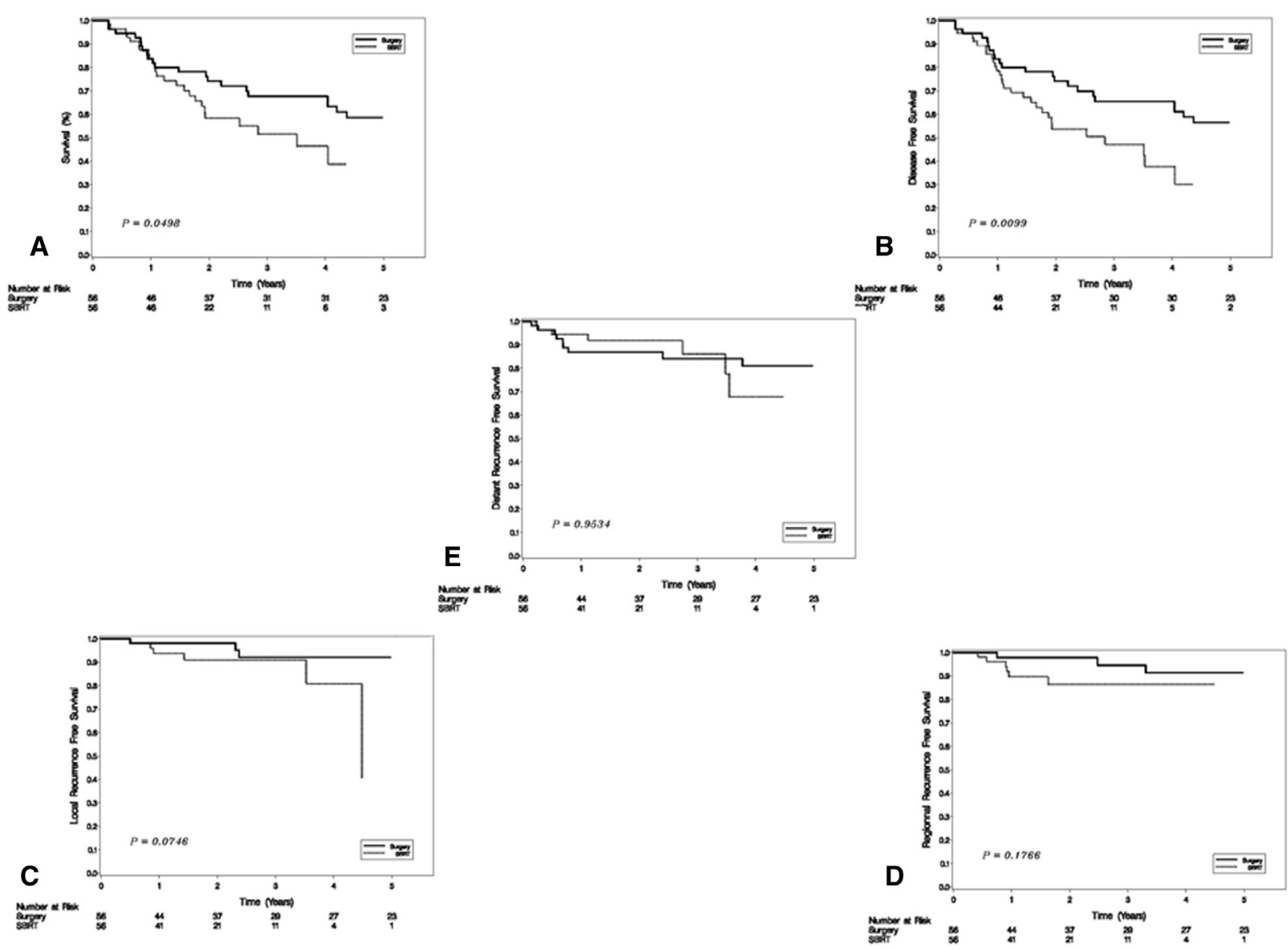

FIGURE 2. Overall survival (A); disease-free survival (B); and freedom from local (C), regional (D), and distant (E) recurrence between the matched cohorts of surgical and SBRT patients matched for age, tumor size, tumor location, $\mathrm{FEV}_{1} \%$, and $\mathrm{ACE}$ comorbidity score. Final propensity matching resulted in 56 patients in each cohort. $S B R T$, Stereotactic body radiation therapy; $F E V_{1}$, forced expiratory volume in the first second of expiration; $A C E$, Adult Comorbidity Evaluation.

Surgical techniques were consistent throughout the study period. However, the dose of radiation administered for SBRT did change over time after identifying that doses less than $100 \mathrm{~Gy}_{10}$ were associated with higher local recurrence rates and worse OS in clinical studies. ${ }^{20,21}$ In this analysis, only 7 of 151 patients received less than 100 $\mathrm{Gy}_{10}$, with no statistically significant difference in OS or local recurrence based on the dose.

Within the SBRT cohort, $14 \%$ of patients were treated without conclusive biopsy proof of cancer when an attempt at tissue diagnosis was unsuccessful, or when a needle biopsy was not pursued based on the perceived high risk of pneumothorax. There was no difference in OS or freedom from local recurrence among SBRT patients with or without a tissue diagnosis before treatment (Figure E2).

Most patients within the surgical cohort were treated with lobectomy (347 of 458, 75.8\%). Pneumonectomy or bilobectomy was performed in $5.9 \%$ (27), and $18.3 \%(84)$ were treated with sublobar resection. Among the sublobar resections, $41.7 \%$ (35) were anatomic resections (segmentectomy) and 58.3\% (49) were nonanatomic wedge resections. Tumor margin distance was not recorded in these patients. There was no difference in OS between the different types of resections performed. In the unmatched comparison, local recurrence rates after lobectomy, sublobar resection, and SBRT were $1.73 \%(\mathrm{n}=6), 7.14 \%(\mathrm{n}=6)$, and $10.67 \%$ $(\mathrm{n}=16)$, respectively $(P<.0001$ lobectomy vs SBRT, $P=.02$ lobectomy vs sublobar resection, $P=.5$ sublobar resection vs SBRT).

Among the 458 patients with clinical stage I lung cancer, $14.8 \%(68 / 458)$ were upstaged at surgery and found to have occult N1 or N2 disease. For patients with occult nodal disease, 3 -year and 5-year OS were $66 \%$ and $43 \%$, respectively. For patients without occult nodal disease, 3 - and 5-year OS were $80 \%$ and $68 \%$, respectively.

In an attempt to account for disparate cohorts, propensity matching was performed to identify 2 similar groups of patients within the SBRT and surgery cohorts for comparison. Age, ACE-27 score, and T status were used for propensity score estimation based on previous publications by us and 
TABLE 1. Patient and disease characteristics for unmatched patients

\begin{tabular}{|c|c|c|c|}
\hline Variable & SBRT $(n=151)$ & Surgery $(n=458)$ & $P$ value \\
\hline Mean age, $\mathrm{y} \pm \mathrm{SD}$ & $74.4 \pm 9.4$ & $65.8 \pm 10.5$ & $<.0001$ \\
\hline Age > 75 y, n (\%) & $73(48.3)$ & $89(19.4)$ & $<.0001$ \\
\hline Male, n (\%) & $80(53.0)$ & $212(46.3)$ & .1535 \\
\hline \multicolumn{4}{|l|}{ Race, $\mathrm{n}(\%) \dagger$} \\
\hline White & $132(88.0)$ & $403(88.0)$ & \\
\hline Black & $16(10.7)$ & $50(10.9)$ & .9686 \\
\hline Asian & $2(1.3)$ & $5(1.1)$ & \\
\hline Weight, $\mathrm{kg} \pm \mathrm{SD}_{\ddagger}$ & $78.9 \pm 22.3$ & $78.5 \pm 20.9$ & .7391 \\
\hline $\mathrm{T} 2, \mathrm{n}(\%)$ & $41(27.2)$ & $165(36.0)$ & .0456 \\
\hline Comorbidity score, $\mathrm{n}(\%) \dagger$ & & & $<.0001$ \\
\hline $0-1$ & $37(32.7)$ & $268(64.1)$ & \\
\hline $2-3$ & $76(67.3)$ & $150(35.9)$ & \\
\hline Smoking, $\mathrm{n}(\%) \dagger$ & & & .2567 \\
\hline Yes & $126(85.1)$ & $406(88.7)$ & \\
\hline No & $22(14.9)$ & $52(11.4)$ & \\
\hline Hypertension, $\mathrm{n}(\%) \ddagger$ & & & .7003 \\
\hline Yes & $90(63.4)$ & $136(65.4)$ & \\
\hline No & $52(36.6)$ & $72(34.6)$ & \\
\hline Size of tumor, $\mathrm{cm} \pm \mathrm{SD}$ & $2.6 \pm 1.0$ & $2.9 \pm 1.7$ & .4522 \\
\hline Location of tumor, $\mathrm{n}(\%)$ & & & $<.0001$ \\
\hline Peripheral & $122(84.1)$ & $277(66.4)$ & \\
\hline Central & $23(15.9)$ & $140(33.6)$ & \\
\hline $\mathrm{FEV}_{1}, \mathrm{~L}$, mean $\pm \mathrm{SD}_{\ddagger}^{\ddagger}$ & $1.4 \pm 0.7(\mathrm{n}=95)$ & $2.1 \pm 0.8(\mathrm{n}=449)$ & $<.0001$ \\
\hline $\mathrm{FEV}_{1}, \mathrm{~L}$, mean $\% \pm \mathrm{SD}_{\ddagger}^{\dagger}$ & $57 \pm 25(\mathrm{n}=94)$ & $79 \pm 20(\mathrm{n}=444)$ & $<.0001$ \\
\hline DLCO, mL, mean $\pm \mathrm{SD}_{\ddagger}^{\dagger}$ & $10.8 \pm 4.9(\mathrm{n}=59)$ & $16.2 \pm 6.2(\mathrm{n}=387)$ & $<.0001$ \\
\hline DLCO, $\mathrm{mL}$, mean $\% \pm \mathrm{SD}_{\uparrow}^{\dagger}$ & $53 \pm 24(\mathrm{n}=67)$ & $74 \pm 25(\mathrm{n}=382)$ & $<.0001$ \\
\hline \multicolumn{4}{|l|}{ Surgery procedure type, $\mathrm{n}(\%)$} \\
\hline Bilobectomy & - & $10(2.2)$ & \\
\hline Lobectomy & - & $347(75.8)$ & \\
\hline Pneumonectomy & - & $17(3.7)$ & \\
\hline Segmentectomy & - & $35(7.6)$ & \\
\hline Wedge & - & $49(10.7)$ & \\
\hline
\end{tabular}

$\overline{S D}$, Standard deviation; $F E V_{l}$, forced expiratory volume in the first second of expiration; $D L C O$, diffusing capacity of lung for carbon monoxide; $S B R T$, stereotactic body radiation therapy. *Chi-squared or Fisher exact test for categorical variables; Kruskal-Wallis test for continuous variables. †The denominator for the percentages is the sum of patients across all categories in the SBRT or surgery group, respectively, excluding missing values. $\ddagger$ High frequency of missing values.

others. ${ }^{2,17,18}$ With the propensity-matched model, 83 patients were matched from each of the cohorts. For the matched comparison, 3-year OS was $75 \%$ for surgery versus $47 \%$ for SBRT $(P<.0004)$ (Figure E3 and Appendix E3). Three-year DFS for surgery was $67 \%$ versus $42 \%$ for SBRT $(P<.0002)$. Three-year freedom from local recurrence for the surgical cohort was $97 \%$ versus $90 \%$ for the SBRT cohort $(P<.01)$. Three-year freedom from regional recurrence and from distant recurrence did not differ between the matched cohorts.

Recognizing the limitations of these previously used matching criteria, we attempted to include additional factors that may influence patient selection for each treatment. We therefore performed an additional propensity-matched comparison that used age, tumor size, tumor location (central vs peripheral), $\mathrm{FEV}_{1} \%$, and $\mathrm{ACE}$ comorbidity score. This resulted in 56 matched patients in each cohort. Table 3 outlines characteristics of each matched cohort. Figure 2 outlines overall survival, disease-free survival, and local recurrence-free survival among these matched groups (confidence intervals provided in Appendix E4). In the final matched comparison, 3 -year overall survival was $52 \%$ versus $68 \%$ for SBRT and surgery, respectively $(P=.05)$, whereas disease-free

TABLE 2. Total proportion of local, regional, and distant recurrences occurring in all patients with stage 1 NSCLC treated with surgery or SBRT

\begin{tabular}{lcccc}
\hline & No recurrence (\%) & Local recurrence $(\%)$ & Regional recurrence $(\%)$ & Distant recurrence $(\%)$ \\
\hline Surgery & 77.7 & 2.6 & 7.0 & 12.7 \\
SBRT & 66 & 10.7 & 10 & 13.3 \\
\hline
\end{tabular}

SBRT, Stereotactic body radiation therapy. 
TABLE 3. Patient and disease characteristics for matched patients*

\begin{tabular}{|c|c|c|c|}
\hline Variable & SBRT $(n=56)$ & Surgery $(n=56)$ & $P$ value \\
\hline Age, mean $\mathrm{y} \pm \mathrm{SD}$ & $70.7 \pm 10.6$ & $70.0 \pm 8.1$ & 6496 \\
\hline Age >75 y, n (\%) & $20(35.7)$ & $16(28.6)$ & .4183 \\
\hline Male, n (\%) & $29(51.8)$ & $32(57.1)$ & .5692 \\
\hline Race, n $(\%) \ddagger$ & & & .3207 \\
\hline White & $49(89.1)$ & $53(94.6)$ & \\
\hline Black & $6(10.9)$ & $3(5.4)$ & \\
\hline Weight $(\mathrm{lb}) \S$ & $175.6 \pm 54.5$ & $164.3 \pm 44.1$ & .3355 \\
\hline $\mathrm{T} 2, \mathrm{n}(\%)$ & $16(28.6)$ & $24(42.9)$ & .1147 \\
\hline Comorbidity score, n (\%) & & & .5702 \\
\hline $2-3$ & $31(55.4)$ & $28(50.0)$ & \\
\hline Smoking, $\mathrm{n}(\%) \ddagger$ & & & .2060 \\
\hline Yes & $51(92.7)$ & $55(98.2)$ & \\
\hline No & $4(7.3)$ & $1(1.8)$ & \\
\hline Hypertension, $\mathrm{n}(\%) \ddagger$ & & & 6989 \\
\hline Yes & $33(62.3)$ & $6(75.0)$ & \\
\hline No & $20(37.7)$ & $2(25.0)$ & \\
\hline Size of tumor, $\mathrm{mm} \pm \mathrm{SD}$ & $2.5 \pm 1.1$ & $3.0 \pm 1.6$ & .3095 \\
\hline Location of tumor, n (\%) & & & .3408 \\
\hline Peripheral & $49(87.5)$ & $52(92.9)$ & \\
\hline Central & $7(12.5)$ & $4(7.1)$ & \\
\hline $\mathrm{FEV}_{1}$, mean $\pm \mathrm{SD}_{\ddagger}^{\dagger}$ & $1.6 \pm 0.7$ & $1.6 \pm 0.6$ & .6156 \\
\hline $\mathrm{FEV}_{1}$, mean $\% \pm \mathrm{SD}$ & $64 \pm 24$ & $62 \pm 18$ & .8522 \\
\hline DLco, mean $\pm \mathrm{SD} \S$ & $11.6 \pm 5.3$ & $14.3 \pm 4.8$ & .0020 \\
\hline DLCo, mean $\% \pm \mathrm{SD} \S$ & $55 \pm 20$ & $73 \pm 27$ & .0001 \\
\hline \multicolumn{4}{|l|}{ Surgery procedure type, $\mathrm{n}(\%)$} \\
\hline Bilobectomy & - & $1(1.8)$ & \\
\hline Lobectomy & - & $44(78.6)$ & \\
\hline Pneumonectomy & - & 0 & \\
\hline Segmentectomy & - & $6(10.7)$ & \\
\hline Wedge & - & $5(8.9)$ & \\
\hline
\end{tabular}

$S B R T$, Stereotactic body radiation therapy; $S D$, standard deviation; $F E V_{l}$, forced expiratory volume in the first second of expiration; $D L C O$, diffusing capacity of lung for carbon monoxide. *Age, comorbidity score, $\mathrm{FEV}_{1}(\%)$, tumor location, and tumor size were used for propensity score estimation. c-statistics is 0.824 . The matched pair is found using a caliper technique with a standard deviation defined as 0.075 of the estimated propensity score for both groups. †Chi-squared or Fisher exact test for categorical variables; Kruskal-Wallis test for continuous variables. †The denominator for the percentages is the sum of patients across all categories in the SBRT or surgery group, excluding missing values. §Missing values.

survival was $47 \%$ versus $65 \%(P=.01)$. Two-, $3-, 4-$, and 5 -year local recurrence-free survival for SBRT was $91 \%$, $91 \%, 81 \%$, and $40 \%$, respectively, versus $98 \%, 92 \%$, $92 \%$, and $92 \%$ for surgery $(P=.07)$. Regional and distant recurrence-free survival were again similar among the groups.

\section{DISCUSSION}

The development and more widespread use of ablative nonoperative treatment modalities for stage I NSCLC such as SBRT and radiofrequency ablation have prompted us to further evaluate the role of these therapies relative to surgical resection. Comparative studies of these modalities have been limited in number and are often difficult to interpret because of variability in methodological issues. Although this current study is retrospective, we have attempted to rigorously compare SBRT and surgical resection in stage I NSCLC outcomes using strictly defined local and regional recurrence criteria accepted by National
Cancer Institute cooperative groups. ${ }^{19}$ These data highlight the challenges and limitations of attempting to match disparate groups of patients retrospectively for a comparative survival analysis. The final matched analysis included one third of the original SBRT cohort and one ninth of the surgery cohort. This final matched comparison suggests improved OS and DFS with surgery versus SBRT with a trend toward improved local recurrence-free survival, albeit not statistically significant in this small cohort. Despite our efforts to match patients retrospectively, it remains difficult to objectively define which subset of high-risk patients would benefit from one modality versus the other.

As expected, OS is better in unmatched surgical patients compared with patients treated with SBRT generally because of a higher burden of comorbidities in the SBRT cohort. Likewise, despite our efforts at matching patients, other unmeasured covariates may be taken into consideration when deeming a patient fit for surgery. One 
variable included in the final matched comparison was pretreatment $\mathrm{FEV}_{1}$, which was documented in only $62 \%$ of patients treated with SBRT versus $97 \%$ of surgical patients. Therefore, this excludes several patients in the SBRT group who were available for comparison (ie, $\mathrm{n}=56$ ) compared with our initial matched comparison that included age, tumor stage, and comorbidity score (ie, $\mathrm{n}=83$ ). Although $\mathrm{FEV}_{1}$ is frequently used to risk stratify surgical patients, the exclusion of this variable in a significant number of patients treated with SBRT highlights that other potentially unmeasured covariates may weigh in the decision to pursue nonoperative treatment at our institution.

In previously published studies, cancer-specific survival has been similar in matched cohorts of patients. ${ }^{6,18,22,23}$ Given that the ACOSOG/RTOG randomized trial used OS and DFS end points, we elected to use these end points. We recognize that they may be considered biased for surgical treatment as noncancer-related mortality may occur more frequently in very high-risk patients undergoing SBRT. Alternatively, cause-specific survival is a favored end point for treatment modalities when patients have a high likelihood of mortality from associated comorbidities. Although survival outcomes seem intuitive, the consistent use of similar outcome measures for patients treated surgically and with SBRT will be important in future comparative studies.

Given the median follow-up of 2.8 years and a predominance of lobar resections, the local recurrence rate of $2.6 \%$ is similar to other reported series of comparable surgical resections. ${ }^{10,24}$ A previous publication from our institution excluding sublobar resections demonstrated similar postoperative recurrence patterns. ${ }^{23}$ True local recurrence after lobectomy would likely be limited to a stump recurrence. Higher local recurrence rates have been reported within the surgical literature, sometimes attributed to inclusion of all locoregional recurrences within the local recurrence definition. ${ }^{25}$ Surgical cohorts with a larger proportion of nonanatomic sublobar resections may also result in a higher reported local recurrence rate as staple line recurrence would occur with greater frequency. Inclusion of more central lesions requiring pneumonectomy/bilobectomy may result in a higher reported local recurrence rate although this represented a small proportion of resections in this study.

The overall local recurrence rate after SBRT was $10.7 \%$ in this series. Within the SBRT literature, various definitions of recurrence have been used to report outcomes from focal ablative therapy. Recurrence outcomes may include primary tumor site recurrence, marginal recurrence, or intralobar recurrence. ${ }^{3,7,23,26}$ Recognizing the variability in the definitions of recurrence in both the SBRT and surgical literature, one of the strengths of this report is that similar criteria were used to define local recurrence between the 2 cohorts. A potential criticism of this analysis is that we chose to limit our evaluation of recurrence to first recurrence, a commonly reported end point in the surgical literature.

Anatomic resection, particularly lobectomy, has been associated with excellent long-term survival ranging from $65 \%$ to $80 \%$ for stage I NSCLC. ${ }^{9-11,27}$ Furthermore, contemporary series of minimally invasive lobectomy have been associated with minimal perioperative mortality and 5-year OS ranging from 75\% to $90 \% .^{10,11,28}$ Ongoing surgical trials are attempting to identify the role of sublobar resection in stage I lung cancer, but the predominance of lobectomy in this series highlights our institutional bias toward lobar resection, reserving sublobar resection for high-risk patients with poor pulmonary reserve. An ongoing challenge with clinical trials, as well as within clinical practice, is that current guidelines defining the high-risk patient are subjective and prone to physician bias. A recent secondary analysis of clinical trial inclusion criteria for SBRT underscored this bias by demonstrating that many patients who were considered inoperable were perhaps reasonable surgical candidates. ${ }^{29}$ In the absence of a clinical trial or a prospective database, there is currently no objective algorithm to guide the assignment of surgery versus SBRT.

Attempts to objectively stratify risk within the surgical population have been challenging. Other published work at our institution has suggested that the Charlson Comorbidity Score may serve as a better measure of comorbidity than the ACE score in these populations. ${ }^{30}$ Other risk models based on the European Thoracic Database and the Society of Thoracic Surgeons Database have attempted to model perioperative morbidity, length of stay, and assessment of quality of care in thoracic surgery across all surgical patients. These models are not yet robust enough to guide decision making regarding treatment assignment or classification of the very high-risk surgical patient for whom alternative therapies may be preferable. ${ }^{31-33}$ In conjunction with this, alternative outcome measures such as toxicity, quality of life, and functional capacity after treatment are important components of comparative studies. As comorbidity increases and life expectancy decreases, it is reasonable to presume that patientreported outcomes such as health-related quality of life will take on higher importance compared with absolute OS. We must be cognizant that patients may be willing to sacrifice some long-term survival benefit related to surgery for a potential preservation of quality of life that may be presumed to be associated with SBRT treatment. Any attempt to construct an algorithm to guide treatment decisions in these patients must pay attention to patient preferences and the factors that guide such preferences.

In this study, $14.8 \%$ of clinical stage I patients were ultimately found to have nodal disease at resection with a 
5 -year OS of $43 \%$. Given current clinical staging techniques, some patients with involved nodes are likely missed in the SBRT group. Our reported incidence of occult nodal disease after resection in these clinical stage I patients is similar to that observed in other reports. ${ }^{10,16}$ Overall, $19.4 \%$ of clinical stage I patients treated with surgery were eventually shown to be pathologic stage II, III, or IV. Furthermore, patients with a higher $\mathrm{T}$ stage than clinically predicted may also affect local recurrence rates among patients treated with SBRT. Future improvements in clinical staging with identification of occult nodal or metastatic disease may allow for earlier use of adjuvant treatment in patients treated with SBRT.

This study presents a concerted effort to use trial-based guidelines to compare outcomes between different treatment modalities in patients with stage I lung cancer. This work highlights some of the current limitations of retrospective comparative studies in disparate populations. The apparent advantages of surgery in terms of OS and DFS, and potentially local recurrence, will still need to be confirmed in a prospective randomized fashion. A reasonable goal for work like this would be to improve our ability to draw on objective data to guide the allocation of appropriate treatment in patients with stage I lung cancer at increased risk for perioperative death and surgical complications.

\section{References}

1. Bradley JD, El Naqa I, Drzymala RE, Trovo M, Jones G, Denning MD. Stereotactic body radiation therapy for early-stage non-small-cell lung cancer: the pattern of failure is distant. Int J Radiat Oncol Biol Phys. 2010;77:1146-50.

2. Lagerwaard FJ, Verstegen NE, Haasbeek CJ, Slotman BJ, Paul MA, Smit EF, et al. Outcomes of stereotactic ablative radiotherapy in patients with potentially operable stage I non-small cell lung cancer. Int J Radiat Oncol Biol Phys. 2012; $83: 348-53$.

3. Onishi H, Shirato H, Nagata Y, Hiraoka M, Fujino M, Gomi K, et al. Stereotactic body radiotherapy (SBRT) for operable stage I non-small-cell lung cancer: can SBRT be comparable to surgery? Int J Radiat Oncol Biol Phys. 2011;81:1352-8.

4. Shibamoto Y, Hashizume C, Baba F, Ayakawa S, Manabe Y, Nagai A, et al. Stereotactic body radiotherapy using a radiobiology-based regimen for stage I nonsmall cell lung cancer: a multicenter study. Cancer. 2012;118:2078-84.

5. Onishi H, Araki T, Shirato H, Nagata Y, Hiraoka M, Gomi K, et al. Stereotactic hypofractionated high-dose irradiation for stage I nonsmall cell lung carcinoma: clinical outcomes in 245 subjects in a Japanese multiinstitutional study. Cancer. 2004;101:1623-31

6. Ricardi U, Filippi A, Guarneri A, Giglioli F, Ciammella P, Franco P, et al. Stereotactic body radiation therapy for early stage non-small cell lung cancer: results of a prospective trial. Lung Cancer. 2010;68:72-7.

7. Timmerman R, Paulus R, Galvin J, Michalski J, Straube W, Bradley J, et al. Stereotactic body radiation therapy for inoperable early stage lung cancer. JAMA. 2010;303:1070-6.

8. Darling GE, Allen MS, Decker PA, Ballman K, Malthaner RA, Inculet RI, et al. Number of lymph nodes harvested from a mediastinal lymphadenectomy: results of the randomized, prospective American College of Surgeons Oncology Group Z0030 trial. Chest. 2011;139:1124-9.

9. Ginsberg RJ, Rubinstein LV. Randomized trial of lobectomy versus limited resection for T1 N0 non-small cell lung cancer. Lung Cancer Study Group. Ann Thorac Surg. 1995;60:615-22; discussion 622-3.

10. Flores RM, Ihekweazu UN, Rizk N, Dycoco J, Bains MS, Downey RJ, et al. Patterns of recurrence and incidence of second primary tumors after lobectomy by means of video-assisted thoracoscopic surgery (VATS) versus thoracotomy for lung cancer. J Thorac Cardiovasc Surg. 2011;141:59-64.
11. McKenna RJ Jr. New approaches to the minimally invasive treatment of lung cancer. Cancer J. 2005;11:73-6.

12. Paul S, Altorki NK, Sheng S, Lee PC, Harpole DH, Onaitis MW, et al. Thoracoscopic lobectomy is associated with lower morbidity than open lobectomy: a propensity-matched analysis from the STS database. J Thorac Cardiovasc Surg. 2010;139:366-78.

13. Louie AV, Rodrigues G, Hannouf M, Zaric GS, Plama DA, Cao JQ, et al. Stereotactic body radiotherapy versus surgery for medically operable Stage I non-small-cell lung cancer: a Markov model-based decision analysis. Int J Radiat Oncol Biol Phys. 2011;81:964-73.

14. Fernando HC, Landreneau RJ, Mandrekar SJ, Hillman SL, Nichols FC, Meyers B, et al. Thirty- and ninety-day outcomes after sublobar resection with and without brachytherapy for non-small cell lung cancer: results from a multicenter phase III study. J Thorac Cardiovasc Surg. 2011;142:1143-51.

15. Fernando HC, Timmerman R. American College of Surgeons Oncology Group Z4099/Radiation Therapy Oncology Group 1021: a randomized study of sublobar resection compared with stereotactic body radiotherapy for high-risk stage I non-small cell lung cancer. J Thorac Cardiovasc Surg. 2012; $144:$ S35-8.

16. Crabtree TD, Denlinger CE, Meyers BF, El Naqa I, Zoole J, Krupnick AS, et al. Stereotactic body radiation therapy versus surgical resection for stage I non-small cell lung cancer. J Thorac Cardiovasc Surg. 2010;140:377-86.

17. Puri V, Crabtree TD, Kymes S, Gregory M, Bell J, Bradley JD, et al. A comparison of surgical intervention and stereotactic body radiation therapy for stage I lung cancer in high-risk patients: a decision analysis. J Thorac Cardiovasc Surg. 2012;143:428-36.

18. Robinson CG, El Naqa I, Crabtree T, Meyers B, Puri V, Zoole J, et al. Outcomes after stereotactic body radiation therapy (SBRT) or anatomic surgical resection (ASR) for clinical stage I non-small cell lung cancer. Int J Radiat Oncol Biol Phys. 2010;78:S15.

19. Surgery with or without internal radiation therapy compared with stereotactic body radiation therapy in treating patients with high-risk stage I non-small cell lung cancer. Available at: http://clinicaltrials.gov/ct2/show/ NCT01336894?term=Z4099\&rank=1. Accessed April 2013.

20. Olsen JR, Robinson CG, El Naqa I, Creach KM, Drzymala RE, Bloch C, et al. Dose-response for stereotactic body radiotherapy in early-stage non-small-cell lung cancer. Int J Radiat Oncol Biol Phys. 2011;81:e299-303.

21. Onishi H, Shirato H, Nagata Y, Hiraoka M, Fujino M, Gomi K, et al. Hypofractionated stereotactic radiotherapy (HypoFXSRT) for stage I non-small cell lung cancer: updated results of 257 patients in a Japanese multi-institutional study. J Thorac Oncol. 2007;2(7 Suppl 3):S94-100.

22. Andratschke N, Zimmermann F, Boehm E, Schill S, Schoenknecht C, Thamm R, et al. Stereotactic radiotherapy of histologically proven inoperable stage I non-small cell lung cancer: patterns of failure. Radiother Oncol. 2011;101:245-9.

23. Robinson CG, DeWees TA, El Naqa I, Creach KM, Olsen JR, Crabtree TD, et al. Patterns of failure after stereotactic body radiation therapy or lobar resection for clinical stage I non-small-cell lung cancer. J Thorac Oncol. 2013;8:192-201.

24. Martini N, Bains MS, Burt ME, Zakowski MF, McCormack P, Rusch V, et al. Incidence of local recurrence and second primary tumors in resected stage I lung cancer. J Thorac Cardiovasc Surg. 1995;109:120-9.

25. Kelsey CR, Marks LB, Hollis D, Hubbs JL, Ready NE, D'Amico TA, et al. Local recurrence after surgery for early stage lung cancer: an 11-year experience with 975 patients. Cancer. 2009;115:5218-27.

26. Senthi S, Lagerwaard FJ, Haasbeek CJ, Slotman BJ, Senan S. Patterns of disease recurrence after stereotactic ablative radiotherapy for early stage non-small-cell lung cancer: a retrospective analysis. Lancet Oncol. 2012;13:802-9.

27. Goldstraw P, Crowley J, Chansky K, Giroux DJ, Groome PA, Rami-Porta R, et al. The IASLC Lung Cancer Staging Project: proposals for the revision of the TNM stage groupings in the forthcoming (seventh) edition of the TNM Classification of malignant tumours. J Thorac Oncol. 2007;2:706-14.

28. Flores RM, Park BJ, Dycoco J, Aronova A, Hirth Y, Rizk NP, et al. Lobectomy by video-assisted thoracic surgery (VATS) versus thoracotomy for lung cancer. J Thorac Cardiovasc Surg. 2009;138:11-8.

29. Crabtree T, Puri V, Timmerman R, Fernando H, Bradley J, Decker PA, et al. Treatment of stage I lung cancer in high-risk and inoperable patients: comparison of prospective clinical trials using stereotactic body radiotherapy (RTOG 0236), sublobar resection (ACOSOG Z4032), and radiofrequency ablation (ACOSOG Z4033). J Thorac Cardiovasc Surg. 2013;145:692-9.

30. DeWees TA, Creach KM, Olsen JR, Bradley JD, Robinson CG. Defining optimal comorbidity measures for patients with medically inoperable 
early-stage non-small cell lung cancer (NSCLC) treated with stereotactic body radiation therapy (SBRT). Int J Radiat Oncol Biol Phys. 2012;84:S172.

31. Brunelli A, Berrisford RG, Rocco G, Varela G. The European Thoracic Database project: composite performance score to measure quality of care after major lung resection. Eur J Cardiothorac Surg. 2009;35:769-74.

32. Kozower BD, Sheng S, O'Brien SM, Liptay MJ, Lau CL, Jones DR, et al. STS database risk models: predictors of mortality and major morbidity for lung cancer resection. Ann Thorac Surg. 2010;90:875-81; discussion 881-3.

33. Wright CD, Gaissert HA, Grab JD, O'Brien SM, Peterson ED, Allen MS, Predictors of prolonged length of stay after lobectomy for lung cancer: a Society of Thoracic Surgeons General Thoracic Surgery Database risk-adjustment model. Ann Thorac Surg. 2008;85:1857-65; discussion 1865.

\section{Discussion}

Dr James D. Luketich (Pittsburgh, Pa). Dr Crabtree, I would like to congratulate you and your colleagues for a very timely look at the significant increase we are seeing in referral patients for stereotactic radiation therapy for stage I non-small cell lung cancer. My first question relates to the absolute proportion of stage I patients during this time frame that were referred to stereotactic radiosurgery of approximately $25 \%$. Given the study is now 3 to 4 years old, are you seeing an increase in that number of $25 \%$ that are actually getting stereotactic radiosurgery, and along those lines, is the technology changing? CyberKnife, Trilogy, TrueBeam, is there a single device they are using? Have you seen any advantages or any comments of one technology over the other?

Regarding the absolute results, you pointed out several things in the comparison between these groups, and the total comparison and propensity match showed a significant advantage in the surgical group at 3 and 5 years in terms of disease-free survival. Yet in the more detailed analysis, there is a lack of a clinically significant difference in the regional recurrence, survival or distant, and in the propensity-matched groups only a modest improvement in local recurrence. So it seems that SBRT is working fairly good locally. So if patients are not having local or regional recurrence at a higher rate, ultimately can you comment more on the cancer-specific survival? I see that difference in disease-free survival, and how are you determining at the time of death in this retrospective review that it was indeed cancer-related or were you able to do that?

Dr Crabtree. Thank you, Dr Luketich. Great points. The first point, I don't have the specific numbers or the percentages of patients that we have sent to stereotactic radiotherapy over the time of the study. I would say, generally speaking, over that time our number of evaluations of clinical stage I lung cancers has gone up, and perhaps the percentage of stereotactic patients has gone up slightly as a result of us making an assessment that it may be adequate in those patients.

I think what we have seen as we have delved into this newer technology of stereotactic therapy is we have had patients come out of the woodwork who probably historically would never have been treated at all or never been evaluated for treatment. Now that referring physicians are aware of this technology, I think we are seeing more of those, and that probably accounts for most of the higher percentage of stereotactic patients that we have seen in this study.

The second question I think is a very important point, and I highlighted it in the first point of the conclusions. It is very difficult for us to match these patients, because they're very disparate populations. Most of the survival difference that we see in terms of disease-free survival and overall survival is likely attributed to some other comorbidities. I will say, however, that the radiation oncologists make the argument that, because in this population we see no difference in regional failure or distant failure, that is an advantage or an argument for stereotactic radiotherapy. We are still seeing a difference in local recurrence, which I think is extremely important, and compared with lobectomy, there is about a 5-fold increase in local recurrence in the stereotactic group.

One more comment on that. The theory that the radiation oncologists have is that there is some kind of immune effect, that treating a tumor focally with stereotactic therapy somehow affects the nodal disease. My potential common sense theory is that at 3 years, $53 \%$ of the stereotactic patients are dead and at 5 years $75 \%$ are dead, and we clearly are not very good at defining recurrences radiographically in the nonliving patient.

Dr Scott Swanson (Boston, Mass). I really enjoyed your talk, Traves. Along those same lines, I have a couple of questions. One, $15 \%$ nodal disease was seen in your surgical cohort, so presumably that is true on the radiation side, but yet you couldn't demonstrate a local regional failure. So what is your impression or hypothesis about what happens to those patients?

And number 2, it seems important to really understand morbidity. Do you have any data on morbidity for the radiation patients? It can't be zero, so it is always a little later that you see these radiation side effects. Are you following these patients and getting a sense for pneumonias, pulmonary fibrosis, issues around respiration, because I think with minimally invasive techniques, our morbidity is pretty limited, and I don't really understand what it is for SBRT.

Dr Crabtree. Thank you, Dr Swanson. Again, great points. Again, although there is certainly a higher local recurrence rate for stereotactic therapy compared with surgery, in terms of regional and distant recurrences, when we are treating these very sick patients with multiple comorbidities with stereotactic therapy, I think that their mortality prevents us from being able to identify regional and distant recurrences, and I think trying to extrapolate that data and say that there is some equivalence in a low-risk population is inappropriate. But we would only be able to answer that question as more low-risk patients who are surviving are treated with stereotactic therapy.

The second question is a very important point, because we certainly take a lot of heat in terms of 30- and 90-day morbidity in the resected patients. In contrast, most of the stereotactic complications occur 6 months to even a year out, including radiation pneumonitis, rib fractures, and pain, and it's actually very hard to track those complications in the stereotactic patients.

For purposes of this study, however, I do not have accurate data on the morbidity of stereotactic therapy.

Dr Nasser Altorki (New York, NY). One of the hardest things is to document local recurrence after SBRT. Many times I find that if you operate on these patients for failure, you will find that they have a small number of interspersed cancer cells within a dense desmoplastic stroma. How was that done in your study and do you have any insights into how we do it, documentation of local recurrence in the SBRT arm?

Dr Crabtree. In this population it was almost all radiographic, and, as you know, in the stereotactic patients, there is controversy 
in determining based on CT and PET whether or not something represents a recurrence. This was actually very challenging to work through with our radiation oncologists, but I reviewed every one of the cases with the radiation oncologist and determined radiographically if it was a recurrence.

It should be, in a low-risk population, that we get tissue confirmation. In this population, that just wasn't practical.

Dr Arjun Pennathur (Pittsburgh, Pa). With the concern of limiting toxicity of stereotactic radiosurgery in central lesions and adjustment of dose taking into account the location of the tumor, could you tell us how many of them were peripheral lesions and how many of them were central lesions, because that in itself has an implication in terms of toxicity as well as the outcome for the patients.

The second thing is the issue of tissue diagnosis. Fifteen percent of the SBRT patients did not have a tissue diagnosis, and in your propensity matching, you matched for $\mathrm{T}$ stage and other factors, but could you have considered eliminating the patients who did not have a tissue diagnosis at all from the propensity matching to get that out of the equation, because some of these patients in whom you did not have a tissue diagnosis could have had benign disease or they could have had something like carcinoid or small cell cancer or something else.

Dr Crabtree. Excellent point. The first question about whether they were central or peripheral, most of these lesions were peripheral lesions, partly because obviously the radiation oncologists know there is more toxicity with the central lesions, and so most central lesions are currently being done on study.

For the second question, I think that is very important for us to also understand in the literature. In our SBRT group for this study, $14 \%$ didn't have a tissue diagnosis. I did include them because it is kind of the practical nature of the practice. We did a subgroup analysis comparing survival and recurrence of the patients who had a tissue diagnosis and those who didn't, and there was no difference. That is a somewhat crude way to deal with this issue. That number of $14 \%$ is actually much lower than what it was in our original publication a few years ago.

I would highlight that the Dutch group, who publishes quite a bit on stereotactic radiotherapy, purports an algorithm based on PET that can completely clinically predict whether or not someone has a cancer, and in their most recent publication, only one-third of the patients actually had a tissue diagnosis, and I think that would be unacceptable, in a low-risk operable population. There is nothing better to improve your cancer-specific survival than treating granulomas with stereotactic therapy.

Dr David C. Rice (Houston, Tex). Traves, a great paper. I really hate to advocate on behalf of the radiation oncologists here, but, as you point out, the comorbidity score probably doesn't take into account resectability, and, therefore, did you go back and look at the patients who were treated with radiation to see what their pulmonary function was, how many of those could not possibly have a lobectomy anyhow? It seems to me that the comparison is a little slanted in favor of the lobectomy group here.

Dr Crabtree. That is another great question. Certainly the ACE comorbidity score that we used was a somewhat crude measure. The problem is identifying this high-risk population or even the inoperable population. Even within our Society, we don't truly know who these high-risk patients are. Efforts with the Thoracoscore and the STS database by Dr Boffa and Dr Wright and Ben Kozower, and even Dr Ferguson yesterday, really shows that these risk models are not yet robust enough to allow us to truly identify these high-risk patients.

We did look at pulmonary function in the surgical group, but because of other comorbidities as well, the data on pulmonary function were incomplete in the stereotactic group. 


\section{APPENDIX E1. ADULT COMORBIDITY}

EVALUATION-27

Identify the important medical comorbidities and grade severity using the index. Overall comorbidity score is defined according to the highest ranked single ailment, except when 2 or more grade 2 ailments occur in different organ systems. In this situation, the overall comorbidity score should be designated as grade 3 .

\begin{tabular}{lll}
\hline \multicolumn{1}{c}{ Cogent comorbid ailment } & Grade 3: severe decompensation & Grade 2: moderate decompensation \\
\hline Cardiovascular system & & \\
Myocardial infarct & $\leq 6 \mathrm{mo}$ ago & $>6 \mathrm{mo}$ ago \\
Angina/coronary artery disease & Unstable angina & Chronic exertional angina \\
& & Recent $(\leq 6 \mathrm{mo})$ CABG or PTCA \\
& & Recent $(\leq 6 \mathrm{mo})$ coronary stent
\end{tabular}

CHF

Arrhythmias

Hypertension

Venous disease

Peripheral arterial disease

\section{Gastrointestinal system}

Hepatic

\section{Respiratory system}

\section{Hospitalized for $\mathrm{CHF}$ within past 6 mo \\ Ejection fraction $<20 \%$}

Ventricular arrhythmia $\leq 6 \mathrm{mo}$

DBP $\geq 13 \mathrm{~mm} \mathrm{Hg}$

Severe malignant papilledema or other eye changes

Encephalopathy

Recent PE ( $\leq 6 \mathrm{mo})$

Use of venous filter for PE

Bypass or amputation for gangrene or arterial insufficiency $<6$ mo ago

Untreated thoracic or abdominal aneurysm $(\geq 6 \mathrm{~cm})$

Marked pulmonary insufficiency Restrictive lung disease or COPD with dyspnea at rest despite treatment

Chronic supplemental $\mathrm{O}_{2}$

$\mathrm{CO}_{2}$ retention $\left(\mathrm{PCO}_{2}>5 \mathrm{~mm} \mathrm{Hg}\right)$

Baseline $\mathrm{PO}_{2}<50 \mathrm{~mm} \mathrm{Hg}$

$\mathrm{FEV}_{1}(<50 \%)$

Portal hypertension and/or esophageal bleeding $\leq 6$ mo (encephalopathy, ascites, jaundice with total bilirubin $>2 \mathrm{mg} / \mathrm{dL}$ )
Hospitalized for CHF $>6$ mo before

CHF with dyspnea that limits activities

Ventricular arrhythmia $>6$ mo Chronic atrial fibrillation or flutter Pacemaker

$\mathrm{DBP}=115-129 \mathrm{~mm} \mathrm{Hg}$

$\mathrm{DBP}=90-114 \mathrm{~mm} \mathrm{Hg}$ while taking antihypertensive medications

Secondary cardiovascular symptoms: vertigo, epistaxis, headaches

DVT controlled with coumadin or heparin

Old PE $>6$ mo

Bypass or amputation for gangrene or arterial insufficiency $>6$ mo ago

Chronic insufficiency

Restrictive lung disease or COPD (chronic bronchitis, emphysema, or asthma) with dyspnea that limits activities

FEV $_{1}(51 \%-65 \%)$

Chronic hepatitis, cirrhosis, portal hypertension with moderate symptoms, compensated hepatic failure
Grade 1: mild decompensation

By ECG only, age undetermined

ECG or stress test evidence or catheterization evidence of coronary disease without symptoms

Angina pectoris not requiring hospitalization

CABG or PTCA $(>6$ mo)

Coronary stent $(>6 \mathrm{mo})$

CHF with dyspnea that has responded to treatment

Exertional dyspnea

Paroxysmal nocturnal dyspnea

Sick sinus syndrome

Supraventricular tachycardia

DBP $=90-114 \mathrm{~mm} \mathrm{Hg}$ while not taking antihypertensive medications

DBP $<9 \mathrm{~mm} \mathrm{Hg}$ while taking antihypertensive medications Hypertension, not otherwise specified Old DVT no longer treated with coumadin or heparin

Intermittent claudication

Untreated thoracic or abdominal aneurysm $(<6 \mathrm{~cm})$

Status post abdominal or thoracic aortic aneurysm repair

Restrictive lung disease or COPD (chronic bronchitis, emphysema, or asthma) with dyspnea that has responded to treatment FEV $_{1}(66 \%-80 \%)$ 
Continued

\begin{tabular}{|c|c|c|}
\hline Cogent comorbid ailment & Grade 3: severe decompensation & Grade 2: moderate decompensation \\
\hline Stomach/intestine & $\begin{array}{l}\text { Recent ulcers }(\leq 6 \text { mo ago) requiring } \\
\text { blood transfusion }\end{array}$ & $\begin{array}{l}\text { Ulcers requiring surgery or } \\
\text { transfusion }>6 \text { mo ago }\end{array}$ \\
\hline Pancreas & $\begin{array}{l}\text { Acute or chronic pancreatitis with } \\
\text { major complications (phlegmon, } \\
\text { abscess, or pseudocyst) }\end{array}$ & $\begin{array}{l}\text { Uncomplicated acute pancreatitis } \\
\text { Chronic pancreatitis with minor } \\
\text { complications (malabsorption, } \\
\text { impaired glucose tolerance, or } \\
\text { gastrointestinal bleeding) }\end{array}$ \\
\hline \multicolumn{3}{|l|}{ Renal system } \\
\hline End-stage renal disease & $\begin{array}{l}\text { Creatinine level }>3 \mathrm{mg} / \mathrm{dL} \text { with } \\
\text { multiorgan failure, shock, or sepsis } \\
\text { Acute dialysis }\end{array}$ & $\begin{array}{l}\text { Chronic renal insufficiency with } \\
\text { creatinine level }>3 \mathrm{mg} / \mathrm{dL} \\
\text { Chronic dialysis }\end{array}$ \\
\hline \multicolumn{3}{|c|}{ Endocrine system (code the comorbid ailments with an asterisk in both the endocrine system and other organ syst } \\
\hline Diabetes mellitus & $\begin{array}{l}\text { Hospitalization } \leq 6 \text { mo for diabetic } \\
\quad \text { ketoacidosis } \\
\text { Diabetes causing end-organ failure } \\
\text { - retinopathy } \\
\text { - neuropathy } \\
\text { - nephropathy } \\
\text { - coronary disease } \\
\text { - peripheral arterial disease }\end{array}$ & $\begin{array}{l}\text { Type } 1 \text { diabetes without } \\
\text { complications } \\
\text { Poorly controlled type } 2 \text { diabetes with } \\
\text { oral agents }\end{array}$ \\
\hline
\end{tabular}

Neurologic system

Stroke

Dementia

Paralysis

Neuromuscular

\section{Psychiatric}

Acute stroke with significant neurologic deficit

Severe dementia requiring full support for activities of daily living

Paraplegia or hemiplegia requiring full support for activities of daily living

MS, Parkinson disease, myasthenia gravis, or other chronic neuromuscular disorder and requiring full support for activities of daily living

Recent suicidal attempt

Active schizophrenia
Old stroke with neurologic residual

Moderate dementia (not completely self-sufficient, needs supervising)

Paraplegia or hemiplegia requiring wheelchair, able to do some self care

MS, Parkinson disease, myasthenia gravis, or other chronic neuromuscular disorder, but able to do some self care

Depression or bipolar disorder uncontrolled

Schizophrenia controlled with medication
Grade 1: mild decompensation

Diagnosis of ulcers treated with medication

Chronic malabsorption syndrome Inflammatory bowel disease on medications or history with complications and/or surgery

Chronic pancreatitis without complications

Chronic renal insufficiency with creatinine level of $2-3 \mathrm{mg} / \mathrm{dL}$

stems if applicable)

Type 2 diabetes controlled by oral agents only

Stroke with no residual

Past or recent transient ischemic attack

Mild dementia (can take care of self)

Paraplegia or hemiplegia, ambulatory and providing most of self care

MS, Parkinson disease, myasthenia gravis, or other chronic neuromuscular disorder, but ambulatory and providing most of self care

Depression or bipolar disorder controlled with medication

Rheumatologic (including rheumatoid arthritis, systemic lupus, mixed connective tissue disorder, polymyositis, rheumatic polymyositis)

Connective tissue disorder with secondary end-organ failure (renal, cardiac, central nervous system)
Connective tissue disorder on steroids

or immunosuppressant medications
Connective tissue disorder on nonsteroidal antiinflammatory drugs or no treatment

Immunologic system (AIDS should not be considered a comorbidity for Kaposi sarcoma or non-Hodgkin lymphoma) AIDS

Fulminant AIDS with Karposi sarcoma, Mycobacterium avium intracellulare, Pneumocystis $\mathrm{HIV}+$ with history of defining illness $\mathrm{CD} 4+<200 / \mu \mathrm{L}$ carinii pneumonia (AIDS-defining illness)
Asymptomatic HIV+ patient HIV+ without history of AIDSdefining illness $\mathrm{CD} 4+>200 / \mu \mathrm{L}$ 
Continued

\begin{tabular}{|c|c|c|c|}
\hline Cogent comorbid ailment & Grade 3: severe decompensation & Grade 2: moderate decompensation & Grade 1: mild decompensation \\
\hline \multicolumn{4}{|c|}{ Malignancy (excluding cutaneous basal cell carcinoma, cutaneous squamous cell carcinoma, carcinoma in situ, and intraepithelial neoplasm) } \\
\hline Solid tumor including melanoma & $\begin{array}{l}\text { Uncontrolled cancer } \\
\text { Newly diagnosed but not yet treated } \\
\text { Metastatic solid tumor }\end{array}$ & $\begin{array}{l}\text { Any controlled solid tumor without } \\
\text { documented metastases, but } \\
\text { initially diagnosed and treated } \\
\text { within the last } 5 \mathrm{y}\end{array}$ & $\begin{array}{l}\text { Any controlled solid tumor without } \\
\text { documented metastases, but } \\
\text { initially diagnosed and treated }>5 \mathrm{y} \\
\text { ago }\end{array}$ \\
\hline Leukemia and myeloma & $\begin{array}{l}\text { Relapse } \\
\text { Disease out of control }\end{array}$ & $\begin{array}{l}\text { First remission or new diagnosis }<1 \text { y } \\
\text { Chronic suppressive therapy }\end{array}$ & $\begin{array}{l}\text { History of leukemia or myeloma with } \\
\text { last treatment }>1 \text { y prior }\end{array}$ \\
\hline Lymphoma & Relapse & $\begin{array}{l}\text { First remission or new diagnosis }<1 \text { y } \\
\text { Chronic suppressive therapy }\end{array}$ & $\begin{array}{l}\text { History of lymphoma with last } \\
\text { treatment }>1 \text { y prior }\end{array}$ \\
\hline \multicolumn{4}{|c|}{ Substance abuse (must be accompanied by social, behavioral, or medical complications) } \\
\hline Alcohol & Delirium tremens & $\begin{array}{l}\text { Active alcohol abuse with social, } \\
\text { behavioral, or medical } \\
\text { complications }\end{array}$ & $\begin{array}{l}\text { History of alcohol abuse but not } \\
\text { presently drinking }\end{array}$ \\
\hline Illicit drugs & Acute withdrawal syndrome & $\begin{array}{l}\text { Active substance abuse with social, } \\
\text { behavioral, or medical } \\
\text { complications }\end{array}$ & $\begin{array}{l}\text { History of substance abuse but not } \\
\text { presently using }\end{array}$ \\
\hline \multicolumn{4}{|l|}{ Body weight } \\
\hline Obesity & & $\begin{array}{l}\text { Morbid (ie, body mass index } \\
\quad \geq 38 \mathrm{~kg} / \mathrm{m}^{2} \text { ) }\end{array}$ & \\
\hline Overall comorbidity score (circle 1 & $\begin{array}{c}0 \\
\text { None }\end{array}$ & $\begin{array}{c}2 \\
\text { Moderate }\end{array}$ & $\begin{array}{c}9 \\
\text { Unknown }\end{array}$ \\
\hline
\end{tabular}

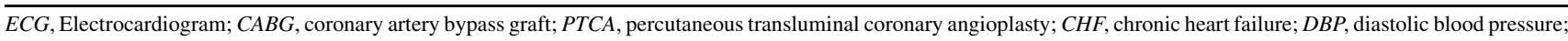
$P E$, pulmonary embolism; $D V T$, deep vein thrombosis; $C O P D$, chronic obstructive pulmonary disease; $F E V_{l}$, forced expiratory volume in the first second of expiration; $M S$, multiple sclerosis; $H I V$, human immunodeficiency virus.

\section{APPENDIX E2}

(1) Overall, (2) disease-free, (3) local-, (4) regional-, and (5) distant recurrence-free survival are presented for the entire cohort of surgical $(n=458)$ and stereotactic body radiation therapy (SBRT, $\mathrm{n}=151$ ) patients with clinical stage I non-small cell lung cancer (including confidence intervals for survival analysis).
1B. Summary of the number of deaths and the number of patients alive at last follow-up (overall survival is defined from date of treatment to date of death or the last follow-up)

\begin{tabular}{lcccc}
\hline & $\begin{array}{c}\text { Total } \\
\text { no. of } \\
\text { patients }\end{array}$ & $\begin{array}{c}\text { Total } \\
\text { no. of } \\
\text { deaths }\end{array}$ & $\begin{array}{c}\text { Total } \\
\text { no. alive } \\
\text { at last } \\
\text { follow-up }\end{array}$ & $\begin{array}{c}\text { Percent alive } \\
\text { at last follow-up }\end{array}$ \\
\hline SBRT & 151 & 81 & 70 & 46.36 \\
Surgery & 458 & 121 & 337 & 73.58 \\
& 609 & 202 & 407 & 66.83 \\
\hline
\end{tabular}

SBRT, Stereotactic body radiation therapy.

\section{C. Overall survival}

1A. From date of treatment to follow-up or death (years). Median follow-up is 2.42 years

\begin{tabular}{lccccc}
\hline Group & $\mathbf{n}$ & Mean & Minimum & Maximum & Median \\
\hline All & 609 & 2.79 & 0.01 & 7.44 & 2.42 \\
Surgery & 458 & 3.00 & 0.01 & 7.44 & 2.83 \\
SBRT & 151 & 2.15 & 0.05 & 6.32 & 1.95 \\
\hline
\end{tabular}

$S B R T$, Stereotactic body radiation therapy.

\begin{tabular}{lccc}
\hline Group & Year & Percent alive & $\mathbf{9 5 \%}$ Confidence interval \\
\hline SBRT & 1 & 0.82 & $(0.75,0.87)$ \\
SBRT & 3 & 0.47 & $(0.37,0.55)$ \\
SBRT & 5 & 0.25 & $(0.14,0.37)$ \\
Surgery & 1 & 0.91 & $(0.88,0.93)$ \\
Surgery & 3 & 0.78 & $(0.73,0.82)$ \\
Surgery & 5 & 0.64 & $(0.58,0.69)$ \\
\hline
\end{tabular}

SBRT, Stereotactic body radiation therapy. 
2A. From date of treatment to disease/death/follow-up (years). Disease free was defined as being alive without disease. The patients with disease or those who died are counted as disease. Disease-free survival was defined as the time from date of treatment to date of cancer recurrence, death or last follow-up

\begin{tabular}{lccccc}
\hline & $\mathbf{n}$ & Mean & Minimum & Maximum & Median \\
\hline All & 609 & 2.71 & 0.01 & 7.44 & 2.28 \\
Surgery & 458 & 2.91 & 0.01 & 7.44 & 2.67 \\
SBRT & 151 & 2.08 & 0.05 & 6.22 & 1.93 \\
\hline
\end{tabular}

$S B R T$, Stereotactic body radiation therapy.

2B. Summary of the number of patients with disease and the number of patients who were disease free at last follow-up

\begin{tabular}{lcccc}
\hline Group & $\begin{array}{c}\text { Total } \\
\text { no. patients }\end{array}$ & $\begin{array}{c}\text { Total } \\
\text { no. with } \\
\text { disease }\end{array}$ & $\begin{array}{c}\text { Total no. } \\
\text { disease } \\
\text { free at last } \\
\text { follow-up }\end{array}$ & $\begin{array}{c}\text { Percent disease } \\
\text { free at last } \\
\text { follow-up }\end{array}$ \\
\hline SBRT & 151 & 91 & 60 & 39.74 \\
Surgery & 458 & 154 & 304 & 66.38 \\
& 609 & 245 & 364 & 59.77 \\
\hline SBRT Stereotactic
\end{tabular}

$S B R T$, Stereotactic body radiation therapy.

2C. Disease-free survival

\begin{tabular}{lccc}
\hline Group & Year & Percent disease free & $\mathbf{9 5} \%$ Confidence interval \\
\hline SBRT & 1 & 0.79 & $(0.72,0.85)$ \\
SBRT & 3 & 0.42 & $(0.33,0.51)$ \\
SBRT & 5 & 0.19 & $(0.10,0.30)$ \\
Surgery & 1 & 0.90 & $(0.87,0.92)$ \\
Surgery & 3 & 0.72 & $(0.67,0.76)$ \\
Surgery & 5 & 0.56 & $(0.49,0.61)$ \\
\hline
\end{tabular}

$S B R T$, Stereotactic body radiation therapy.

3A. From date of treatment to local recurrence/follow-up (years). Local recurrence is defined as having local recurrence or censored at any other recurrences or the last follow-up. Local recurrence-free survival is defined as the time from date of treatment to date of recurrence or last follow-up

\begin{tabular}{|c|c|c|c|c|c|}
\hline Group & $\mathbf{n}$ & Mean & Minimum & Maximum & Median \\
\hline All & 609 & 2.56 & 0.01 & 7.44 & 2.08 \\
\hline Surgery & 458 & 2.78 & 0.01 & 7.44 & 2.31 \\
\hline SBRT & 151 & 1.92 & 0.05 & 6.22 & 1.73 \\
\hline \multicolumn{6}{|c|}{ For the patients who have local recurrence only } \\
\hline Surgery & 12 & 1.69 & 0.24 & 3.90 & 1.45 \\
\hline SBRT & 16 & 1.57 & 0.30 & 4.48 & 1.37 \\
\hline
\end{tabular}

$S B R T$, Stereotactic body radiation therapy.
3B. Summary of the number of patients with local recurrence and the number of patients local recurrence free at last follow-up

\begin{tabular}{|c|c|c|c|c|}
\hline Group & $\begin{array}{c}\text { Total } \\
\text { no. of } \\
\text { patients }\end{array}$ & $\begin{array}{c}\text { Total no. } \\
\text { with local } \\
\text { recurrence }\end{array}$ & $\begin{array}{c}\text { Total } \\
\text { no. local } \\
\text { recurrence } \\
\text { free at last } \\
\text { follow-up }\end{array}$ & $\begin{array}{c}\text { Percent local } \\
\text { recurrence free at } \\
\text { last follow-up }\end{array}$ \\
\hline SBRT & 150 & 16 & 134 & 89.33 \\
\hline \multirow[t]{2}{*}{ Surgery } & 458 & 12 & 446 & 97.38 \\
\hline & 608 & 28 & 580 & 95.39 \\
\hline
\end{tabular}

SBRT, Stereotactic body radiation therapy.

3C. Local recurrence-free survival

\begin{tabular}{lccc}
\hline Group & Year & $\begin{array}{c}\text { Percent local } \\
\text { recurrence free }\end{array}$ & $\mathbf{9 5 \%}$ Confidence interval \\
\hline SBRT & 1 & 0.94 & $(0.89,0.97)$ \\
SBRT & 3 & 0.85 & $(0.75,0.91)$ \\
SBRT & 5 & 0.71 & $(0.44,0.86)$ \\
Surgery & 1 & 0.99 & $(0.97,0.99)$ \\
Surgery & 3 & 0.97 & $(0.94,0.98)$ \\
Surgery & 5 & 0.96 & $(0.92,0.98)$ \\
\hline
\end{tabular}

$S B R T$, Stereotactic body radiation therapy.

4A. From date of treatment to regional recurrence (years) for the patients who have local recurrence only. Regional recurrence is defined as having regional recurrence or censored at any other recurrences or the last follow-up. Regional recurrence-free survival is defined as the time from date of treatment to date of recurrence or last follow-up

\begin{tabular}{lccccc}
\hline Group & $\mathbf{n}$ & Mean & Minimum & Maximum & Median \\
\hline Surgery & 32 & 1.77 & 0.41 & 5.95 & 1.46 \\
SBRT & 15 & 1.37 & 0.18 & 6.22 & 0.92 \\
\hline
\end{tabular}

$S B R T$, Stereotactic body radiation therapy.

4B. Summary of the number of patients with regional recurrence and the number of patients regional recurrence-free at last follow-up

\begin{tabular}{lcccc}
\hline Group & $\begin{array}{c}\text { Total } \\
\text { no. of } \\
\text { patients }\end{array}$ & $\begin{array}{c}\text { Total } \\
\text { no. with } \\
\text { regional } \\
\text { recurrence }\end{array}$ & $\begin{array}{c}\text { Total } \\
\text { no. regional } \\
\text { recurrence } \\
\text { free at last } \\
\text { follow-up }\end{array}$ & $\begin{array}{c}\text { Percent } \\
\text { regional } \\
\text { recurrence } \\
\text { free at last } \\
\text { follow-up }\end{array}$ \\
\hline SBRT & 150 & 15 & 135 & 90.00 \\
Surgery & 458 & 32 & 426 & 93.01 \\
& 608 & 47 & 561 & 92.27 \\
\hline
\end{tabular}

SBRT, Stereotactic body radiation therapy. 
4C. Regional recurrence-free survival

\begin{tabular}{lccc}
\hline Group & Year & $\begin{array}{c}\text { Percent regional } \\
\text { recurrence free }\end{array}$ & $\mathbf{9 5 \%}$ Confidence interval \\
\hline SBRT & 1 & 0.93 & $(0.87,0.96)$ \\
SBRT & 3 & 0.86 & $(0.76,0.92)$ \\
SBRT & 5 & 0.86 & $(0.76,0.92)$ \\
Surgery & 1 & 0.99 & $(0.97,0.99)$ \\
Surgery & 3 & 0.91 & $(0.88,0.94)$ \\
Surgery & 5 & 0.89 & $(0.85,0.93)$ \\
\hline
\end{tabular}

SBRT, Stereotactic body radiation therapy.

5A. From date of treatment to distant recurrence (years) for the patients who have distant recurrence only. Distant recurrence is defined as having distant recurrence or censored at any other recurrences or the last follow-up. Distant recurrence-free survival is defined as the time from date of treatment to date of recurrence or last follow-up

\begin{tabular}{lccccc}
\hline Group & $\mathbf{n}$ & Mean & Minimum & Maximum & Median \\
\hline Surgery & 58 & 1.64 & 0.09 & 6.50 & 1.24 \\
SBRT & 20 & 1.63 & 0.23 & 3.80 & 1.49 \\
\hline
\end{tabular}

SBRT, Stereotactic body radiation therapy.

5B. Summary of the number of patients with distant recurrence and the number of patients distant recurrence free at last follow-up

\begin{tabular}{lcccc}
\hline & $\begin{array}{c}\text { Total } \\
\text { no. of } \\
\text { patients }\end{array}$ & $\begin{array}{c}\text { Total } \\
\text { no. with distant } \\
\text { recurrence }\end{array}$ & $\begin{array}{c}\text { Total no. } \\
\text { distant } \\
\text { recurrence } \\
\text { free at last } \\
\text { follow-up }\end{array}$ & $\begin{array}{c}\text { Percent distant } \\
\text { recurrence free } \\
\text { at last follow-up }\end{array}$ \\
\hline SBRT & 150 & 20 & 130 & 86.67 \\
Surgery & 458 & 58 & 400 & 87.34 \\
& 608 & 78 & 530 & 87.17 \\
\hline
\end{tabular}

SBRT, Stereotactic body radiation therapy.

5C. Distant recurrence-free survival

\begin{tabular}{lccc}
\hline Group & Year & $\begin{array}{c}\text { Percent distant } \\
\text { recurrence free }\end{array}$ & $\mathbf{9 5 \%}$ Confidence interval \\
\hline SBRT & 1 & 0.94 & $(0.88,0.97)$ \\
SBRT & 3 & 0.83 & $(0.72,0.90)$ \\
SBRT & 5 & 0.66 & $(0.47,0.80)$ \\
Surgery & 1 & 0.94 & $(0.91,0.96)$ \\
Surgery & 3 & 0.86 & $(0.82,0.90)$ \\
Surgery & 5 & 0.83 & $(0.77,0.87)$ \\
\hline
\end{tabular}

SBRT, Stereotactic body radiation therapy.

\section{APPENDIX E3}

(1) Overall, (2) disease-free, (3) local-, (4) regional-, and (5) distant recurrence-free survival are presented for the initial propensity-matched comparison based on age, tumor stage, and Adult Comorbidity Evaluation comorbidity score in patients undergoing surgery $(n=83)$ versus stereotactic body radiation therapy $(n=83)$ for clinical stage I non-small cell lung cancer (including confidence intervals for survival analysis).
1A. From date of treatment to follow-up or death (years) for the matched patients. Median follow-up is $\mathbf{2 . 3 4}$ years

\begin{tabular}{lrcccc}
\hline Group & n & Mean & Minimum & Maximum & Median \\
\hline All & 166 & 2.86 & 0.05 & 7.18 & 2.34 \\
Surgery & 83 & 3.43 & 0.08 & 7.18 & 3.58 \\
SBRT & 83 & 2.28 & 0.05 & 6.32 & 1.91 \\
\hline
\end{tabular}

SBRT, Stereotactic body radiation therapy.

1B. Summary of the number of deaths and the number of patients alive at last follow-up. Overall survival is defined from date of treatment to date of death or the last follow-up

\begin{tabular}{lcccc}
\hline & $\begin{array}{c}\text { Total } \\
\text { no. of } \\
\text { patients }\end{array}$ & $\begin{array}{c}\text { Total } \\
\text { no. of } \\
\text { deaths }\end{array}$ & $\begin{array}{c}\text { Total no. } \\
\text { alive at last } \\
\text { follow-up }\end{array}$ & $\begin{array}{c}\text { Percent alive at last } \\
\text { follow-up }\end{array}$ \\
\hline SBRT & 83 & 45 & 38 & 45.78 \\
Surgery & 83 & 31 & 52 & 62.65 \\
& 166 & 76 & 90 & 54.22 \\
\hline
\end{tabular}

SBRT, Stereotactic body radiation therapy.

1C. Overall survival

\begin{tabular}{lccc}
\hline Group & Year & Percent alive & 95\% Confidence interval \\
\hline SBRT & 1 & 0.83 & $(0.73,0.90)$ \\
SBRT & 3 & 0.47 & $(0.35,0.59)$ \\
SBRT & 5 & 0.29 & $(0.16,0.44)$ \\
Surgery & 1 & 0.88 & $(0.78,0.93)$ \\
Surgery & 3 & 0.75 & $(0.63,0.83)$ \\
Surgery & 5 & 0.55 & $(0.42,0.67)$ \\
\hline
\end{tabular}

SBRT, Stereotactic body radiation therapy.

2A. From date of treatment to disease/death/follow-up (years). Disease free was defined as being alive without disease. The patients with disease or those who died are counted as disease. Disease-free survival was defined as the time from date of treatment to date of cancer recurrence, death or last follow-up

\begin{tabular}{lrcccc}
\hline Group & \multicolumn{1}{c}{$\mathbf{n}$} & Mean & Minimum & Maximum & Median \\
\hline All & 166 & 2.74 & 0.05 & 7.18 & 2.20 \\
Surgery & 83 & 3.30 & 0.08 & 7.18 & 3.38 \\
& 83 & 2.17 & 0.05 & 6.22 & 1.89 \\
\hline
\end{tabular}

SBRT, Stereotactic body radiation therapy.

2B. Summary of the number of patients with disease and the number of patients disease free at last follow-up

\begin{tabular}{lcccc}
\hline & Total no. of & $\begin{array}{c}\text { Total no. } \\
\text { disease } \\
\text { patients }\end{array}$ & $\begin{array}{c}\text { with disease } \\
\text { free at last } \\
\text { follow-up }\end{array}$ & $\begin{array}{c}\text { Percent disease } \\
\text { free at last } \\
\text { follow-up }\end{array}$ \\
\hline SBRT & 83 & 52 & 31 & 37.35 \\
Surgery & 83 & 38 & 45 & 54.22 \\
& 166 & 90 & 76 & 45.78 \\
\hline
\end{tabular}

SBRT, Stereotactic body radiation therapy. 
2C. Disease-free survival

\begin{tabular}{lccc}
\hline Group & Year & Percent disease free & $\mathbf{9 5} \%$ Confidence interval \\
\hline SBRT & 1 & 0.79 & $(0.69,0.87)$ \\
SBRT & 3 & 0.42 & $(0.30,0.54)$ \\
SBRT & 5 & 0.21 & $(0.10,0.34)$ \\
Surgery & 1 & 0.88 & $(0.78,0.93)$ \\
Surgery & 3 & 0.67 & $(0.55,0.76)$ \\
Surgery & 5 & 0.47 & $(0.34,0.59)$ \\
\hline
\end{tabular}

$S B R T$, Stereotactic body radiation therapy.

3A. From date of treatment to local recurrence/follow-up (years). Local recurrence is defined as having local recurrence or censored at any other recurrences or the last follow-up. Local recurrence-free survival is defined as the time from date of treatment to date of recurrence or last follow-up

\begin{tabular}{|c|c|c|c|c|c|}
\hline Group & $\mathbf{n}$ & Mean & Minimum & Maximum & Mediar \\
\hline All & 166 & 2.56 & 0.05 & 7.18 & 1.98 \\
\hline Surgery & 83 & 3.07 & 0.08 & 7.18 & 2.96 \\
\hline SBRT & 83 & 2.05 & 0.05 & 6.22 & 1.73 \\
\hline \multicolumn{6}{|c|}{ For the patients who have local recurrence only } \\
\hline Surgery & 2 & 1.25 & 0.96 & 1.53 & 1.25 \\
\hline SBRT & 9 & 1.56 & 0.30 & 4.48 & 0.90 \\
\hline
\end{tabular}

$S B R T$, Stereotactic body radiation therapy.

3B. Summary of the number of patients with local recurrence and the number of patients local recurrence free at last follow-up

\begin{tabular}{lcccc}
\hline Group & $\begin{array}{c}\text { Total no. of } \\
\text { patients }\end{array}$ & $\begin{array}{c}\text { Total no. } \\
\text { with local } \\
\text { recurrence }\end{array}$ & $\begin{array}{c}\text { Total no. } \\
\text { local recurrence } \\
\text { free at last } \\
\text { follow-up }\end{array}$ & $\begin{array}{c}\text { Percent local } \\
\text { recurrence } \\
\text { free at last } \\
\text { follow-up }\end{array}$ \\
\hline SBRT & 83 & 9 & 74 & 89.16 \\
Surgery & 83 & 2 & 81 & 97.59 \\
& 166 & 11 & 155 & 93.37 \\
\hline
\end{tabular}

$S B R T$, Stereotactic body radiation therapy.

3C. Local recurrence-free survival

\begin{tabular}{lccc}
\hline Group & Year & $\begin{array}{c}\text { Percent local } \\
\text { recurrence free }\end{array}$ & $\mathbf{9 5 \%}$ Confidence interval \\
\hline SBRT & 1 & 0.93 & $(0.84,0.97)$ \\
SBRT & 3 & 0.90 & $(0.79,0.95)$ \\
SBRT & 5 & 0.71 & $(0.39,0.88)$ \\
Surgery & 1 & 0.99 & $(0.90,0.998)$ \\
Surgery & 3 & 0.97 & $(0.88,0.99)$ \\
Surgery & 5 & 0.97 & $(0.88,0.99)$ \\
\hline
\end{tabular}

$S B R T$, Stereotactic body radiation therapy.

4A. From date of treatment to regional recurrence (years) for the patients who have distant recurrence only. Regional recurrence is defined as having regional recurrence or censored at any other recurrences or the last follow-up. Regional recurrence-free survival is defined as the time from date of treatment to date of recurrence or last follow-up

\begin{tabular}{lccccc}
\hline Group & n & Mean & Minimum & Maximum & Median \\
\hline Surgery & 9 & 1.91 & 1.21 & 4.31 & 1.37 \\
SBRT & 8 & 1.73 & 0.32 & 6.22 & 0.93 \\
\hline
\end{tabular}

$S B R T$, Stereotactic body radiation therapy.
4B. Summary of the number of patients with regional recurrence and the number of patients regional recurrence free at last follow-up

\begin{tabular}{|c|c|c|c|c|}
\hline Group & $\begin{array}{c}\text { Total no. of } \\
\text { patients }\end{array}$ & $\begin{array}{c}\text { Total no. with } \\
\text { regional } \\
\text { recurrence } \\
\end{array}$ & $\begin{array}{c}\text { Total no. } \\
\text { regional recurrence } \\
\text { free at last } \\
\text { follow-up } \\
\end{array}$ & $\begin{array}{c}\text { Percent } \\
\text { regional } \\
\text { recurrence } \\
\text { free at last } \\
\text { follow-up }\end{array}$ \\
\hline SBRT & 83 & 8 & 75 & 90.36 \\
\hline \multirow[t]{2}{*}{ Surgery } & 83 & 9 & 74 & 89.16 \\
\hline & 166 & 17 & 149 & 89.76 \\
\hline
\end{tabular}

SBRT, Stereotactic body radiation therapy.

4C. Regional recurrence-free survival

\begin{tabular}{lccc}
\hline Group & Year & $\begin{array}{c}\text { Percent regional } \\
\text { recurrence free }\end{array}$ & $\mathbf{9 5 \%}$ Confidence interval \\
\hline SBRT & 1 & 0.93 & $(0.84,0.97)$ \\
SBRT & 3 & 0.87 & $(0.71,0.94)$ \\
SBRT & 5 & 0.87 & $(0.71,0.94)$ \\
Surgery & 1 & 1.00 & \\
Surgery & 3 & 0.89 & $(0.79,0.95)$ \\
Surgery & 5 & 0.83 & $(0.69,0.91)$ \\
\hline
\end{tabular}

SBRT, Stereotactic body radiation therapy.

5A. From date of treatment to distant recurrence (years) for the patients who have distant recurrence only. Distant recurrence is defined as having distant recurrence or censored at any other recurrences or the last follow-up. Distant recurrence-free survival is defined as the time from date of treatment to date of recurrence or last follow-up

\begin{tabular}{lccccc}
\hline Group & $\mathbf{n}$ & Mean & Minimum & Maximum & Median \\
\hline Surgery & 13 & 1.65 & 0.14 & 3.77 & 1.80 \\
SBRT & 15 & 1.80 & 0.23 & 3.80 & 1.55 \\
\hline
\end{tabular}

$S B R T$, Stereotactic body radiation therapy.

5B. Summary of the number of patients with distant recurrence and the number of patients distant recurrence free at last follow-up

Total no. Percent distant

Total no. distant recurrence recurrence Total no. of with distant free at last free at last

\begin{tabular}{lcccc} 
Group & patients & recurrence & follow-up & follow-up \\
\hline SBRT & 83 & 15 & 68 & 81.93 \\
Surgery & 83 & 13 & 70 & 84.34 \\
& 166 & 28 & 138 & 83.13 \\
\hline
\end{tabular}

SBRT, Stereotactic body radiation therapy.

5C. Distant recurrence-free survival

\begin{tabular}{lccc}
\hline Group & Year & $\begin{array}{c}\text { Percent distant } \\
\text { recurrence free }\end{array}$ & $\mathbf{9 5 \%}$ Confidence interval \\
\hline SBRT & 1 & 0.94 & $(0.85,0.97)$ \\
SBRT & 3 & 0.79 & $(0.63,0.89)$ \\
SBRT & 5 & 0.58 & $(0.36,0.75)$ \\
Surgery & 1 & 0.92 & $(0.84,0.96)$ \\
Surgery & 3 & 0.83 & $(0.71,0.90)$ \\
Surgery & 5 & 0.78 & $(0.65,0.87)$ \\
\hline
\end{tabular}

$S B R T$, Stereotactic body radiation therapy. 


\section{APPENDIX E4}

(1) Overall, (2) disease-free, (3) local-, (4) regional-, and (5) distant recurrence-free survival are presented for the final propensity-matched comparison based on age, tumor size, Adult Comorbidity Evaluation comorbidity score, tumor location (central vs peripheral), and forced expiratory volume in the first second of expiration $(\%)$ in patients undergoing surgery $(\mathrm{n}=56)$ versus stereotactic body radiation therapy $(n=56)$ for clinical stage I non-small cell lung cancer (including confidence intervals for survival analysis).

1A. From date of treatment to follow-up or death (years) for the matched patients. Median follow-up is 2.19 years

\begin{tabular}{lrcccc}
\hline Group & \multicolumn{1}{c}{$\mathbf{n}$} & Mean & Minimum & Maximum & Median \\
\hline All & 112 & 2.95 & 0.09 & 7.44 & 2.19 \\
Surgery & 56 & 3.77 & 0.09 & 7.44 & 4.16 \\
SBRT & 56 & 2.13 & 0.26 & 6.04 & 1.88 \\
\hline
\end{tabular}

SBRT, Stereotactic body radiation therapy.

1B. Summary of the number of deaths and the number of patients alive at last follow-up. Overall survival is defined from date of treatment to date of death or the last follow-up

\begin{tabular}{lcccc}
\hline & $\begin{array}{c}\text { Total } \\
\text { no. of } \\
\text { patients }\end{array}$ & $\begin{array}{c}\text { Total } \\
\text { no. of deaths }\end{array}$ & $\begin{array}{c}\text { Total no. alive } \\
\text { at last follow-up }\end{array}$ & $\begin{array}{c}\text { Percent alive at } \\
\text { last follow-up }\end{array}$ \\
\hline SBRT & 56 & 26 & 30 & 53.57 \\
Surgery & 56 & 24 & 32 & 57.14 \\
& 112 & 50 & 62 & 55.36 \\
\hline
\end{tabular}

SBRT, Stereotactic body radiation therapy.

1C. Overall survival

\begin{tabular}{lcclr}
\hline Group & Year & Percent alive & \multicolumn{2}{c}{$\mathbf{9 5 \%}$ Confidence interval } \\
\hline SBRT & 1 & 0.83854 & 0.71263 & 0.91254 \\
SBRT & 2 & 0.58311 & 0.43116 & 0.70764 \\
SBRT & 3 & 0.51629 & 0.35691 & 0.65430 \\
SBRT & 4 & 0.46466 & 0.29405 & 0.61883 \\
SBRT & 5 & 0.38722 & 0.19820 & 0.57340 \\
Surgery & 1 & 0.83636 & 0.70912 & 0.91129 \\
Surgery & 2 & 0.74132 & 0.60220 & 0.83807 \\
Surgery & 3 & 0.67650 & 0.53069 & 0.78578 \\
Surgery & 4 & 0.67650 & 0.53069 & 0.78578 \\
Surgery & 5 & 0.58678 & 0.43679 & 0.70956 \\
\hline SBRT, Sten
\end{tabular}

SBRT, Stereotactic body radiation therapy.

2A. From date of treatment to disease/death/follow-up (years). Disease free was defined as being alive without disease. The patients with disease or those who died are counted as disease. Disease-free survival was defined as the time from date of treatment to date of cancer recurrence, death or last follow-up

\begin{tabular}{lrcccc}
\hline Group & \multicolumn{1}{c}{$\mathbf{n}$} & Mean & Minimum & Maximum & Median \\
\hline All & 112 & 2.89 & 0.09 & 7.44 & 2.14 \\
Surgery & 56 & 3.74 & 0.09 & 7.44 & 4.08 \\
SBRT & 56 & 2.04 & 0.26 & 6.04 & 1.82 \\
\hline
\end{tabular}

SBRT, Stereotactic body radiation therapy.
2B. Summary of the number of patients with disease and the number of patients disease free at last follow-up

\begin{tabular}{lcccc}
\hline & $\begin{array}{c}\text { Total } \\
\text { no. of } \\
\text { patients }\end{array}$ & $\begin{array}{c}\text { Total } \\
\text { no. } \text { with } \\
\text { disease }\end{array}$ & $\begin{array}{c}\text { Total no. } \\
\text { disease free } \\
\text { at last follow-up }\end{array}$ & $\begin{array}{c}\text { Percent disease } \\
\text { free at last follow-up }\end{array}$ \\
\hline SBRT & 56 & 30 & 26 & 46.43 \\
Surgery & 56 & 25 & 31 & 55.36 \\
& 112 & 55 & 57 & 50.89 \\
\hline
\end{tabular}

SBRT, Stereotactic body radiation therapy.

2C. Disease-free survival

\begin{tabular}{lcccc}
\hline Group & Year & Percent disease free & \multicolumn{2}{c}{ 95\% Confidence interval } \\
\hline SBRT & 1 & 0.78571 & 0.65362 & 0.87217 \\
SBRT & 2 & 0.53660 & 0.38889 & 0.66345 \\
SBRT & 3 & 0.47137 & 0.31835 & 0.61005 \\
SBRT & 4 & 0.37710 & 0.21541 & 0.53819 \\
SBRT & 5 & 0.30168 & 0.13331 & 0.49032 \\
Surgery & 1 & 0.83636 & 0.70912 & 0.91129 \\
Surgery & 2 & 0.74132 & 0.60220 & 0.83807 \\
Surgery & 3 & 0.65468 & 0.50745 & 0.76756 \\
Surgery & 4 & 0.65468 & 0.50745 & 0.76756 \\
Surgery & 5 & 0.56577 & 0.41620 & 0.69068 \\
\hline
\end{tabular}

SBRT, Stereotactic body radiation therapy.

3A. From date of treatment to local recurrence/follow-up (years). Local recurrence is defined as having local recurrence or censored at any other recurrences or the last follow-up. Local recurrence-free survival is defined as the time from date of treatment to date of recurrence or last follow-up

\begin{tabular}{|c|c|c|c|c|c|}
\hline Group & $\mathbf{n}$ & Mean & Minimum & Maximum & Mediar \\
\hline All & 112 & 2.78 & 0.09 & 7.44 & 2.14 \\
\hline Surgery & 56 & 3.62 & 0.09 & 7.44 & 3.54 \\
\hline SBRT & 56 & 1.95 & 0.23 & 6.04 & 1.60 \\
\hline \multicolumn{6}{|c|}{ For the patients who have local recurrence only } \\
\hline Surgery & 3 & 1.73 & 0.50 & 2.37 & 2.31 \\
\hline SBRT & 6 & 1.95 & 0.51 & 4.48 & 1.16 \\
\hline
\end{tabular}

$S B R T$, Stereotactic body radiation therapy.

3B. Summary of the number of patients with local recurrence and the number of patients local recurrence free at last follow-up

\begin{tabular}{lcccc}
\hline & $\begin{array}{c}\text { Total } \\
\text { no. of } \\
\text { patients }\end{array}$ & $\begin{array}{c}\text { Total } \\
\text { no. with local } \\
\text { recurrence }\end{array}$ & $\begin{array}{c}\text { Total no. } \\
\text { local recurrence } \\
\text { free at last } \\
\text { follow-up }\end{array}$ & $\begin{array}{c}\text { Percent local } \\
\text { recurrence } \\
\text { free at last } \\
\text { follow-up }\end{array}$ \\
\hline SBRT & 56 & 6 & 50 & 89.29 \\
Surgery & 56 & 3 & 53 & 94.64 \\
& 112 & 9 & 103 & 91.96 \\
\hline
\end{tabular}

SBRT, Stereotactic body radiation therapy. 
3C. Local recurrence-free survival

\begin{tabular}{lcclc}
\hline Group & Year & $\begin{array}{c}\text { Percent local } \\
\text { recurrence free }\end{array}$ & $\mathbf{9 5 \%}$ Confidence interval \\
\hline SBRT & 1 & 0.93830 & 0.82069 & 0.97968 \\
SBRT & 2 & 0.90986 & 0.77449 & 0.96569 \\
SBRT & 3 & 0.90986 & 0.77449 & 0.96569 \\
SBRT & 4 & 0.80877 & 0.50295 & 0.93656 \\
SBRT & 5 & 0.40438 & 0.01373 & 0.82601 \\
Surgery & 1 & 0.98077 & 0.87123 & 0.99727 \\
Surgery & 2 & 0.98077 & 0.87123 & 0.99727 \\
Surgery & 3 & 0.92133 & 0.77097 & 0.97452 \\
Surgery & 4 & 0.92133 & 0.77097 & 0.97452 \\
Surgery & 5 & 0.92133 & 0.77097 & 0.97452 \\
\hline SBRT Sterer
\end{tabular}

SBRT, Stereotactic body radiation therapy.

4A. From date of treatment to regional recurrence (years) for the patients who have local recurrence only. Regional recurrence is defined as having regional recurrence or censored at any other recurrences or the last follow-up. Regional recurrence-free survival is defined as the time from date of treatment to date of recurrence or last follow-up

\begin{tabular}{lccccc}
\hline Group & n & Mean & Minimum & Maximum & Median \\
\hline Surgery & 3 & 2.18 & 0.75 & 3.31 & 2.48 \\
SBRT & 6 & 0.90 & 0.42 & 1.63 & 0.91 \\
\hline
\end{tabular}

$S B R T$, Stereotactic body radiation therapy.

4B. Summary of the number of patients with regional recurrence and the number of patients regional recurrence free at last follow-up

\begin{tabular}{lcccc}
\hline & $\begin{array}{c}\text { Total } \\
\text { no. of } \\
\text { patients }\end{array}$ & $\begin{array}{c}\text { Total no. } \\
\text { with regional } \\
\text { recurrence }\end{array}$ & $\begin{array}{c}\text { Total no. } \\
\text { regional } \\
\text { recurrence } \\
\text { free at last } \\
\text { follow-up }\end{array}$ & $\begin{array}{c}\text { Percent regional } \\
\text { recurrence } \\
\text { free at last } \\
\text { follow-up }\end{array}$ \\
\hline SBRT & 56 & 6 & 50 & 89.29 \\
Surgery & 56 & 3 & 53 & 94.64 \\
& 112 & 9 & 103 & 91.96 \\
\hline
\end{tabular}

$S B R T$, Stereotactic body radiation therapy.

4C. Regional recurrence-free survival

\begin{tabular}{lcclc}
\hline Group & Year & $\begin{array}{c}\text { Percent regional } \\
\text { recurrence free }\end{array}$ & $\mathbf{9 5 \%}$ Confidence interval \\
\hline SBRT & 1 & 0.89715 & 0.77003 & 0.95592 \\
SBRT & 2 & 0.86511 & 0.71924 & 0.93827 \\
SBRT & 3 & 0.86511 & 0.71924 & 0.93827 \\
SBRT & 4 & 0.86511 & 0.71924 & 0.93827 \\
SBRT & 5 & 0.86511 & 0.71924 & 0.93827 \\
Surgery & 1 & 0.97872 & 0.85840 & 0.99698 \\
Surgery & 2 & 0.97872 & 0.85840 & 0.99698 \\
Surgery & 3 & 0.94610 & 0.79511 & 0.98670 \\
Surgery & 4 & 0.91348 & 0.75036 & 0.97189 \\
Surgery & 5 & 0.91348 & 0.75036 & 0.97189 \\
\hline SBRT Stery
\end{tabular}

SBRT, Stereotactic body radiation therapy.
5A. From date of treatment to distant recurrence (years) for the patients who have distant recurrence only. Distant recurrence is defined as having distant recurrence or censored at any other recurrences or the last follow-up. Distant recurrence-free survival is defined as the time from date of treatment to date of recurrence or last follow-up

\begin{tabular}{lrcccc}
\hline Group & $\mathbf{n}$ & Mean & Minimum & Maximum & Median \\
\hline Surgery & 10 & 1.54 & 0.14 & 5.54 & 0.69 \\
SBRT & 7 & 1.70 & 0.23 & 3.55 & 1.11 \\
\hline \multicolumn{5}{l}{ SBRT Stereotactic body radiation therapy. }
\end{tabular}

5B. Summary of the number of patients with distant recurrence and the number of patients distant recurrence free at last follow-up

\begin{tabular}{|c|c|c|c|c|}
\hline Group & $\begin{array}{c}\text { Total no. of } \\
\text { patients }\end{array}$ & $\begin{array}{l}\text { Total no. } \\
\text { with distant } \\
\text { recurrence } \\
\end{array}$ & $\begin{array}{c}\text { Total no. } \\
\text { distant } \\
\text { recurrence } \\
\text { free at last } \\
\text { follow-up }\end{array}$ & $\begin{array}{c}\text { Percent distant } \\
\text { recurrence } \\
\text { free at last } \\
\text { follow-up } \\
\end{array}$ \\
\hline SBRT & 56 & 7 & 49 & 87.50 \\
\hline \multirow[t]{2}{*}{ Surgery } & 56 & 10 & 46 & 82.14 \\
\hline & 112 & 17 & 95 & 84.82 \\
\hline
\end{tabular}

SBRT, Stereotactic body radiation therapy.

5C. Distant recurrence-free survival

\begin{tabular}{lcclc}
\hline Group & Year & $\begin{array}{c}\text { Percent distant } \\
\text { recurrence free }\end{array}$ & $\mathbf{9 5 \%}$ Confidence interval \\
\hline SBRT & 1 & 0.94505 & 0.83914 & 0.98195 \\
SBRT & 2 & 0.91880 & 0.79472 & 0.96927 \\
SBRT & 3 & 0.86138 & 0.66122 & 0.94759 \\
SBRT & 4 & 0.67833 & 0.36853 & 0.85993 \\
SBRT & 5 & 0.67833 & 0.36853 & 0.85993 \\
Surgery & 1 & 0.86875 & 0.74415 & 0.93521 \\
Surgery & 2 & 0.86875 & 0.74415 & 0.93521 \\
Surgery & 3 & 0.84073 & 0.70348 & 0.91798 \\
Surgery & 4 & 0.81070 & 0.66199 & 0.89874 \\
Surgery & 5 & 0.81070 & 0.66199 & 0.89874 \\
\hline SBRT, Stro
\end{tabular}

$S B R T$, Stereotactic body radiation therapy. 

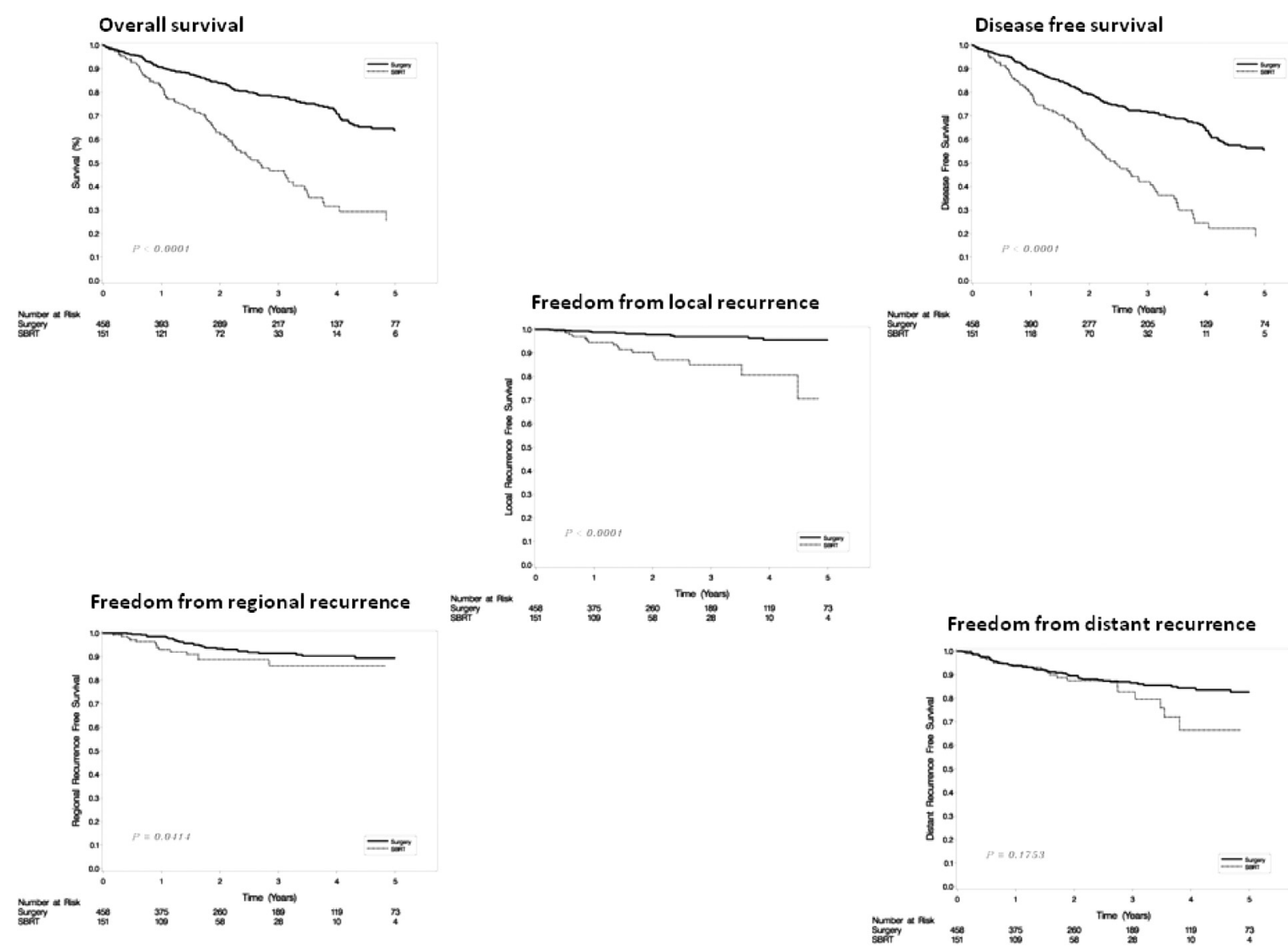

FIGURE E1. Overall, disease-free, local-, regional-, and distant-free recurrence survival for the entire cohort of surgical $(\mathrm{n}=458)$ and SBRT $(\mathrm{n}=151)$ patients with clinical stage I non-small cell lung cancer. SBRT, Stereotactic body radiation therapy.

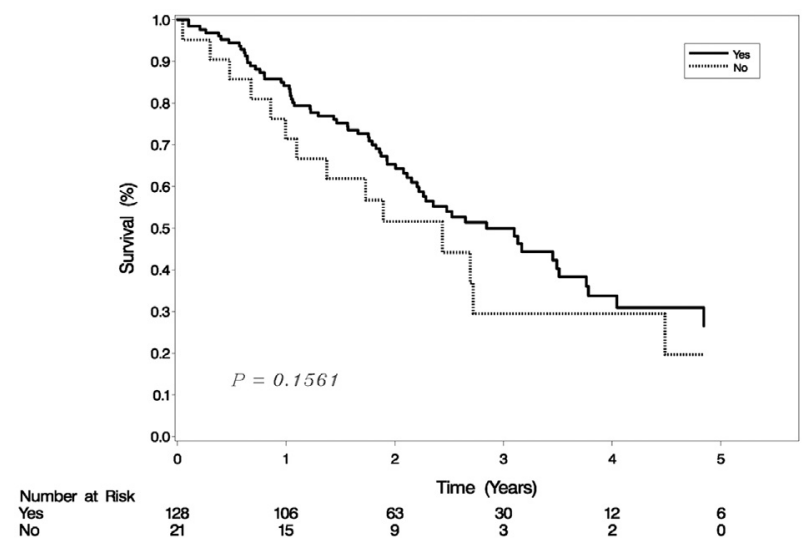

FIGURE E2. Survival for the entire cohort treated with SBRT with versus without a tissue diagnosis of non-small cell lung cancer. 
Overall survival

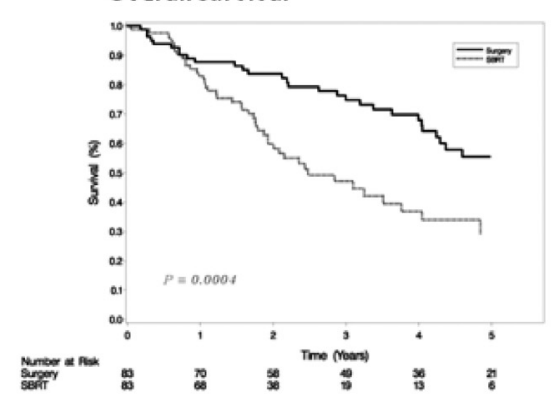

Freedom from regional recurrence

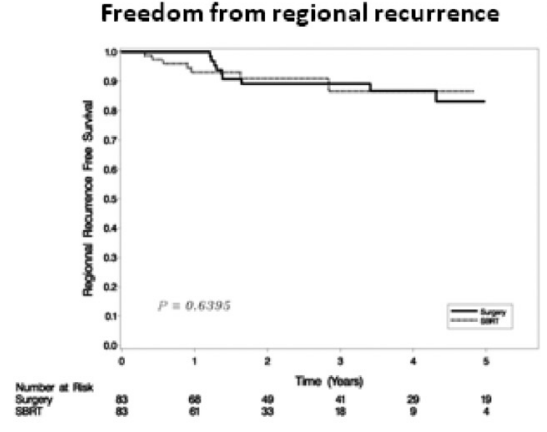

\section{Freedom from local recurrence}

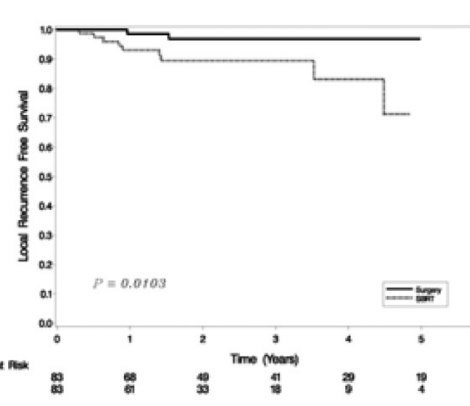

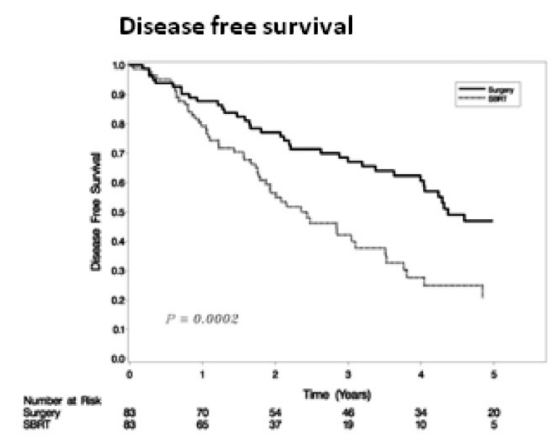

Freedom from distant recurrence

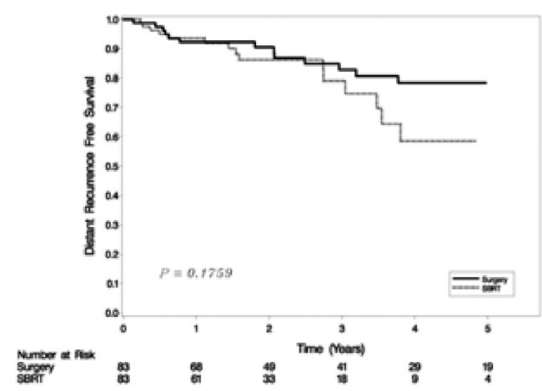

FIGURE E3. Overall, disease-free, local-, regional-, and distant-free recurrence survival for the initial propensity-matched comparison based on age, tumor stage, and Adult Comorbidity Evaluation-27 comorbidity score in patients undergoing surgery $(\mathrm{n}=83)$ versus SBRT $(\mathrm{n}=83)$ for clinical stage I non-small cell lung cancer. SBRT, Stereotactic body radiation therapy. 